\title{
الآثار التربوية للتعليم عن بعد لاى طلاب الجامعات أثناء جائحة كورونا
}

\author{
إعداد \\ ا.د/ فاطمة محمد عبد الوهاب الخليفة \\ أستاذ ورئيس قسم المناهج وطرق التدريس وتكنولوجيا التعليم

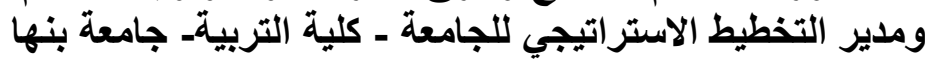

مقدمة:

شهر التعليم العالي تحولاً كبيراً في السنوات الأخيرة، بما في ذلك زيادة الطابع الدولي والاضطر اد في

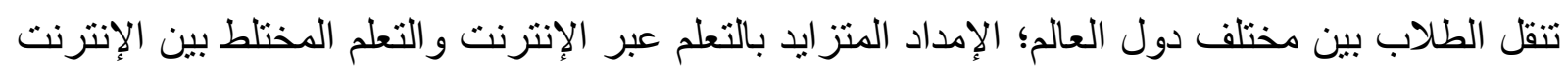

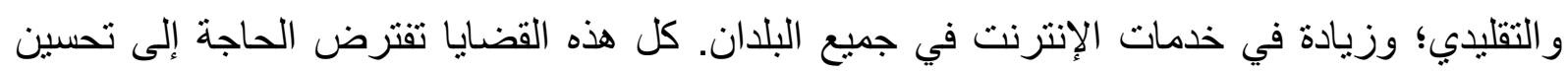

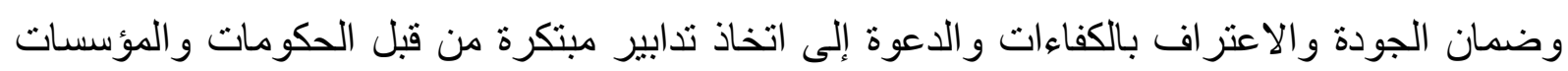

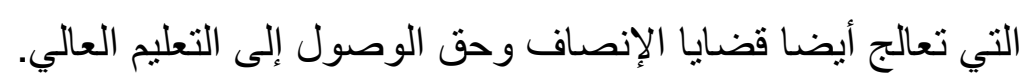

وقد طورت ثروة الموارد التعليمية الرقمية مناهج ابتكارية وبرامج دراسية ومسارات تعليمية بديلة وطرق للتعليم و التعلم بمؤسسات التعليم العالي، وكل ذلك يمكن تيسيره عبر الإنترنت والتعليم عن بعد بلديه

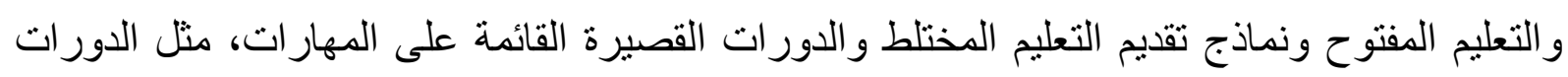

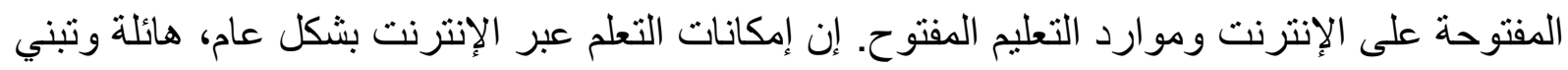

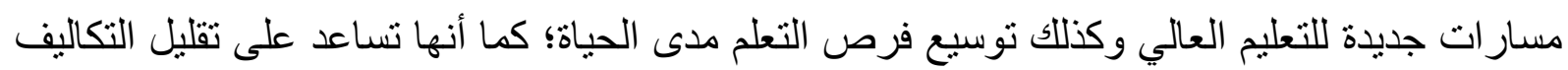
التعليمية الفردية و المؤسسية من خلال تقديم بدائل سهلة ومرنة.

ويمثل هذا فرصة رئيسة لمبتكري المحتوى لتحسين الجودة والإدماج في توفير التعليم العالي. ونوفر

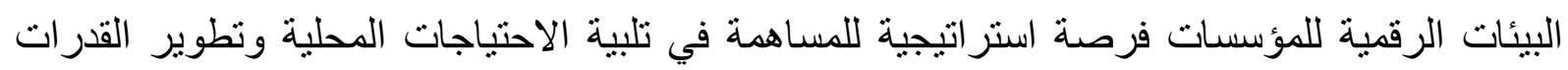
المتعلقة بها. خاصة وضع سياسات وبرامج لتوفير التعليم العالي النوعي والممول تمويلاً جيداً والقائم

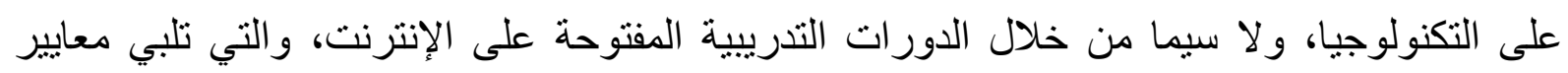
الجودة لتحسين العملية التعليمية.

و إيمانا بان البحث العلمي هو الأداة الفعالة المنوط بها تطوير المجتمع وتأمينه و المساهمة في الخروج

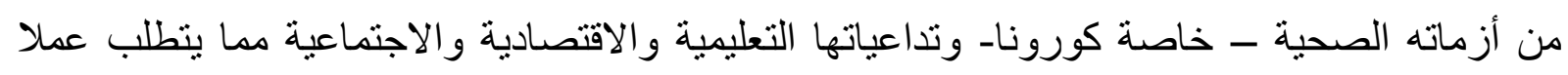


الآثار التريوية للتعليم عن بعد لاى طلاب الجامعات أثناء جائحة كورونا (أ.د/فاطمة محمد عبد الوهاب الخليفة )

علميا منهجيا، و إيمانا بدور الجامعات في التعاطي مع هذه المشكلات وتفسير ها ومحاولة إيجاد حلول علمية تكنولوجية لها، واعتر افا بدور البحث العلمي في خدمة المجتمع وحل مشكلاته والتعرف على تداعيات أزمة كورونا فقد واجهت الجامعات العملية التعليمية خلال هذه الجائحة من خلال نظام التعلم عن بعد كأحد الحلول الممكنة والمتاحة و الرخيصة والآمنة للتعامل مع العملية التعليم و الطلاب. ومثلما اجتاح وباء كورونا المستجد "كوفيد 9 (" حواجز الزمان و المكان، جاءت دعوات "التعلم عن بعد" -التي صاحبث انتشار الفيروس- لتجتاح هي الأخرى حواجز المكان والزمان؛ حيث تم الاجتياح المكاني من غياب الحواجز المكانية الثابتة مثارًا للارتقاء إلى عو الم مختلفة عن طريق شبكات الإنترنت الفسيحة، كما تم الاجتياح الزماني من امتلاك أدوات التخلص من روتين الذهاب والإياب ومزاحمة الآخرين بحثًا عن سر عة الوصول إلى حيز مكاني ربما كان أضيق مما تحتمله رحابة العقول. وقد ذكر تقرير لـ"اليونسكو" أن "انتشار الفيروس سجل رقمًا قياسيًّا للأطفال والثباب الذي انقطعوا عن الذهاب إلى المدرسة أو الجامعة. وحتى تاريخ با مارس، أعلن آج بلدًا في أفريقيا وآسيا وأوروبا والثرق الأوسط وأمريكا الثمالية وأمريكا الجنوبية عن إغلاق المدارس والجامعات، إذ أغلق أكثر من • و بلدًا المدارس في جميع أنحائه، مما أثر على ملايين الطلاب في المراحل الجامعية. ومع انتشار المرض شهد العالم اغلاقا تاما للمدارس و الجامعات في معظم أنحاء العالم، وبكل ما يمتلكه التعلم عن بعد من موارد سمعية وبصرية ورسوم توضيحية وصور متحركة، تحول التعليم عن بعد من أسلوب "التلقين" إلى أسلوب "تفاعلي" مصحوب بمؤثرات بصرية وسمعية، تجعل من العملية التعليمية "الجامدة" عملية أكثر جذبًا، وتساعد الطلاب على الاخول إلى المحتوى دون التوقف عند عتبات رائحة الأوراق.

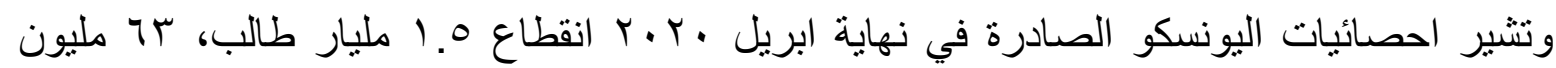
معلما عن مؤسسات التعليم، كما أكدت المنظمة أن ما يعادل نصف عدد هؤلاء الطلاب لا يملكون الاحتياجات اللازمة للتعليم عن بعد.

ومن هنا ظهرت مجموعة من أنظمة إدارة التعلم والبرامج التي تساعد على التعلم عن بعد، ومنها تطبيق "بلاك بورد" (Black Board)، وهو تطبيق يعتمد على تصميم المقررات و المهمات و الو اجبات والاختبار ات وتصحيحها الكترونيا، والتواصل مع الطلاب من خلال بيئة افتراضية وتطبيقات يتم تحميلها عن طريق الهواتف الذكية. وكذلك منصة "إدمودو" (Edmodo)، وهي منصة اجتماعية مجانية توفر للمعلمين و الطلاب بيئةً آمنةً للاتصال و التعاون، وتبادل المحتوى التعليمي وتطبيقاته الرقمية، إضافة إلى الواجبات المنزلية والدرجات و المناقتشات. وتطبيق "إدراك"، المعني بتعليم اللغة العربية عبر الإنترنت، وتطبيق "جوجل كلاسروم" 
الآثار التريوية للتعليم عن بعد لاى طلاب الجامعات أثناء جائحة كورونا (أ.د/فاطمة محمد عبد الوهاب الخليفة )

(Google Classroom)

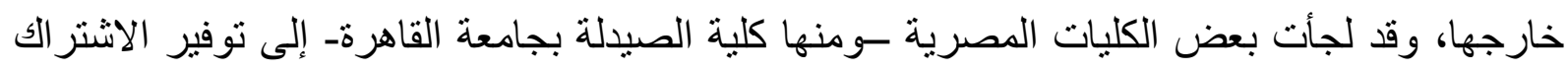
به (مجانًا) لكل طلابها كوسيلة للتعلم عن بعد، وتطبيق "سي سو" (seesaw)، وهو تطبيق رقمي

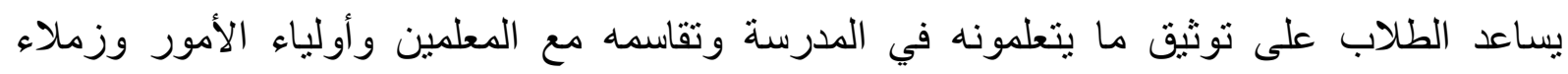

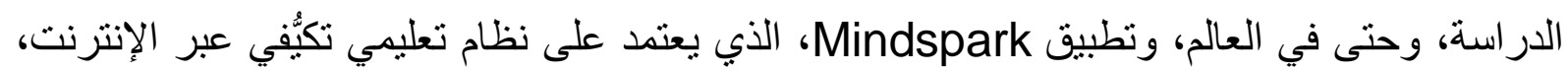
يساعد الطلاب على ممارسة الرياضيات وتعلمها. وتوفر هذه التطبيقات بكل ما تمتلكه من موارد سمعية وبصرية ورسوم توضيحية وصور متحركة،

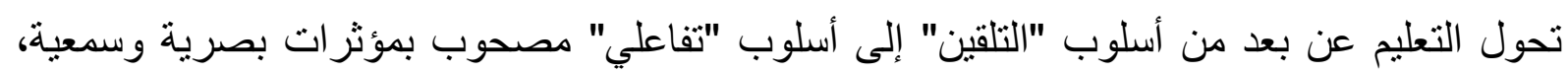

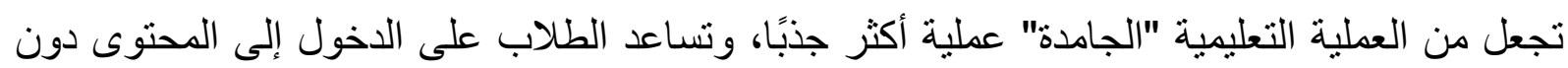

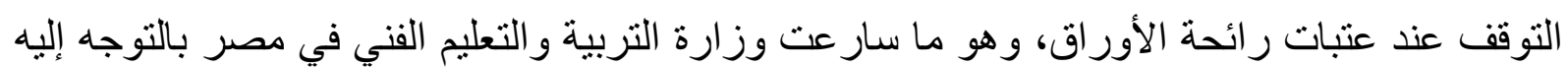
من خلال بنك المعرفة المصري كوسيلة للنغلب على تعليق الدر اسة بها. وقد شهد مركز المعلومات ودعم اتخاذ القرار التابع لمجلس الوزراء المصرب منذ نشأته عام 1910

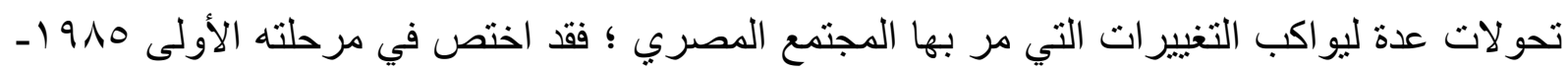

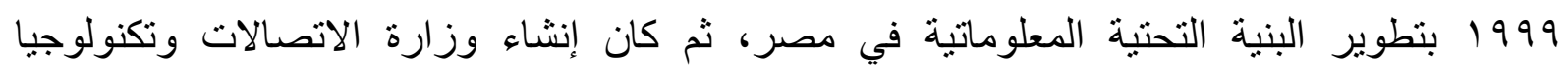
المعلومات نقطة تحول رئيسة في مسيرته، ومنذ ذلك الحين أصبح المركز يتبني رؤية مفادها أن يكون التئه

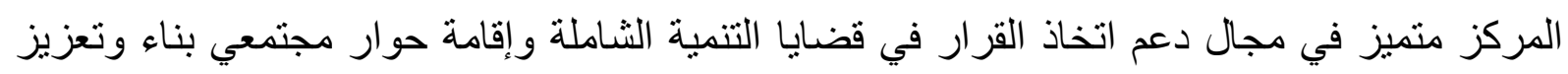

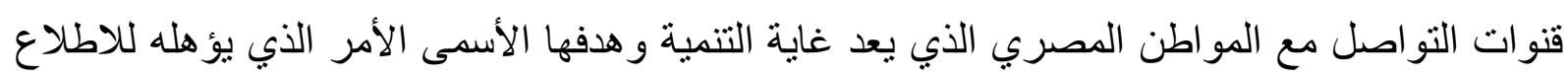

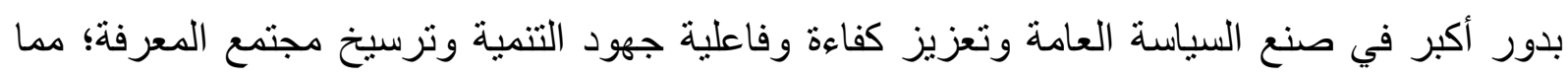
كان له الأثر الإيجابي للتعاطي مع جائحة كورونا من الناحية التعليمية. كما أنشار توماس ج. هوشتيلر، عضو هيئة الاعتماد الأكاديمي (CAA) بوزارة التربية والتعليم

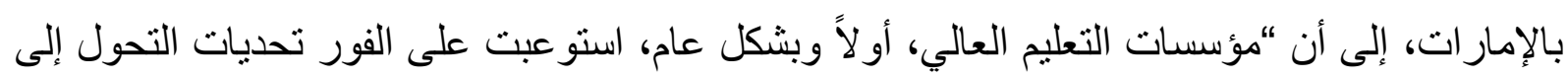

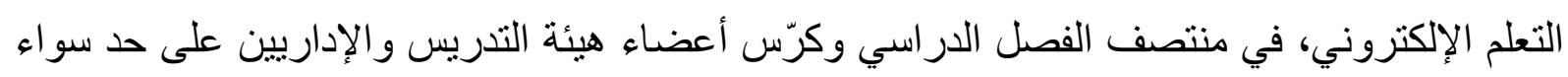
أنفسهم بالكامل لأداء هذه المهمة الثاقة. كما أصبحت العديد من مؤسسات التعليم العالي في طور التكوين كمؤسسات تعليم إلكترونية".

ا. . ويُعرَف التعلُم الإلكتروني بوجه عام بالأسلوب التعليمي الذى يُقام من خلاله المحتوى

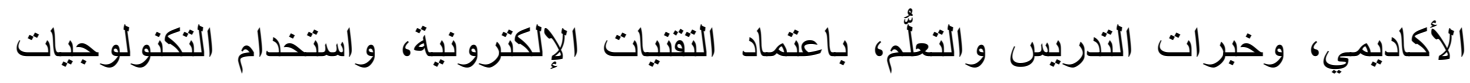

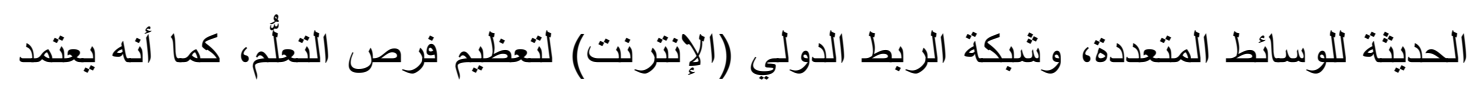


الآثار التريوية للتعليم عن بعد لاى طلاب الجامعات أثناء جائحة كورونا (أ.د/فاطمة محمد عبد الوهاب الخليفة )

على بيئة إلكترونية رقمية متكاملة، تعرض المقررات الدراسية عبر الثبكات الإكترونية، وتوفر سُبل الإرشاد و التوجيه وتنظيم الاختبار ات، وكذللك إدارة الدصادر و العطليات التعليمية وتقويمها،

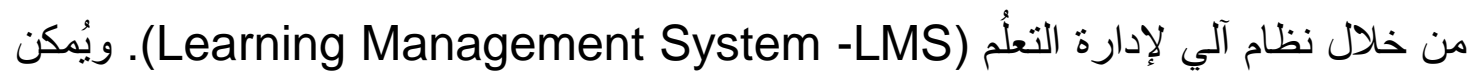
تصنيف منهجية التعلُم الإلكتروني من حيث أسلوب تطبيقه إلى نوعين رئيسيين هما التَعلُم

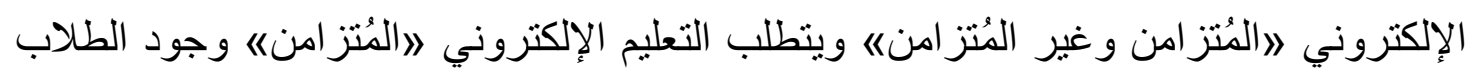

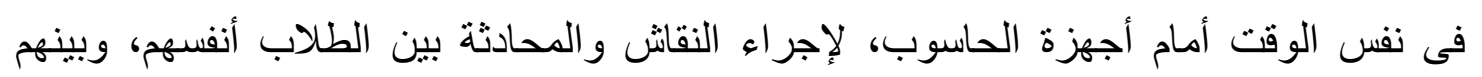

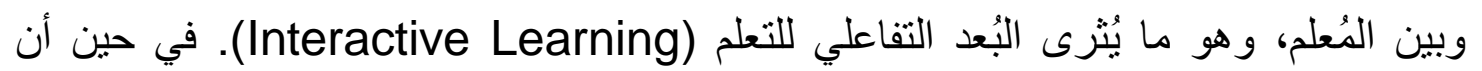
التعليم الإلكتروني 》غير المُتزامنه لا يحتاج إلى وجود الطلاب في نفس الوقت، حيث يتمكن

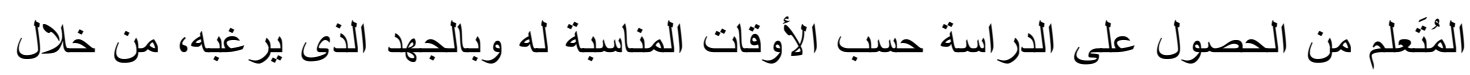

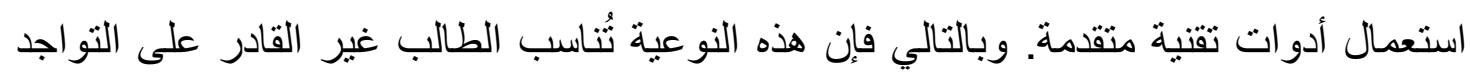

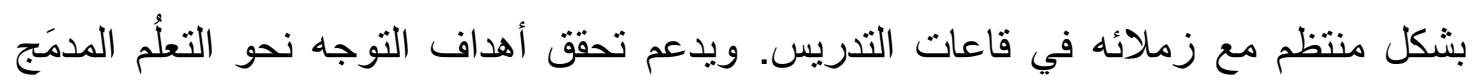
المعتمد على أسلوب التعليم الإكتروني، وجود إطار متكامل للتعلُّم عن بُعد ( Distance

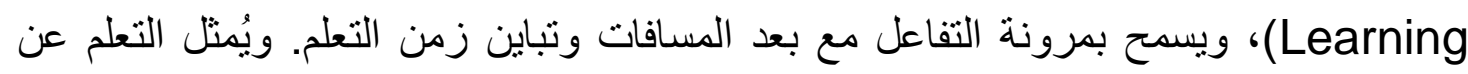
بُعد أحد طرق التعليم الحديثة نسبيًا، التي نَعتمد على وجود المتعلم في مكان يختلف عن مكان

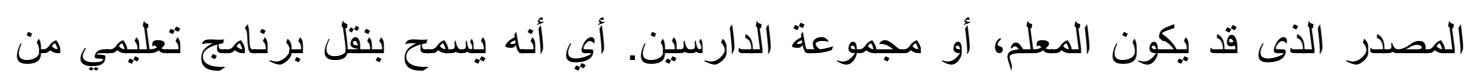

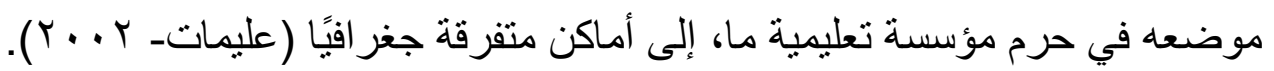
ومن ثَم فإنه يهدف إلى جذب طلاب لا يستطيعون تحت الظروف العادية الاستمرار في برنامج

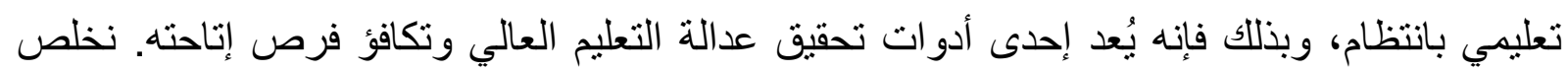
مما سبق، إلى أن التحول من التعليم التقليدي وجها لوجه إلى منظومة التعلم عن بعد هو الاختيار الأمثل

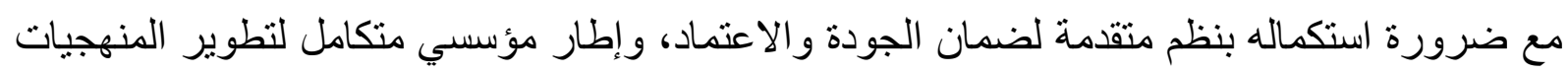

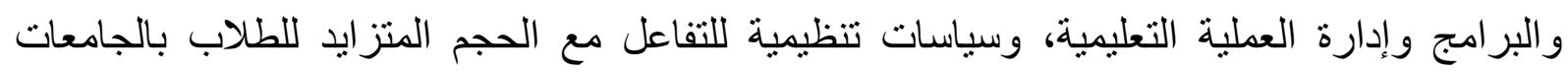

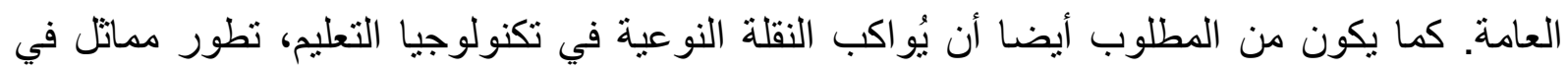

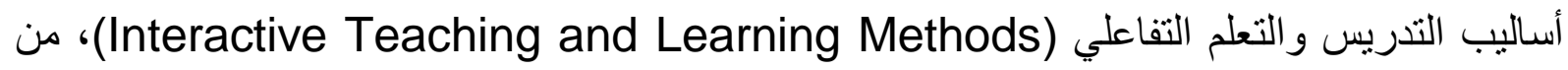
أجل بناء شخصية الخريج، وإكسابه الجدارات الذهنية والمهارات المعرفية التي تتطلبها أسواق العمل بالألفية الثالثة.

وقد أجريت العديد من الدراسات السابقة حول التعلم عن بعد والتعلم التكنولوجي ومنها، دراسة

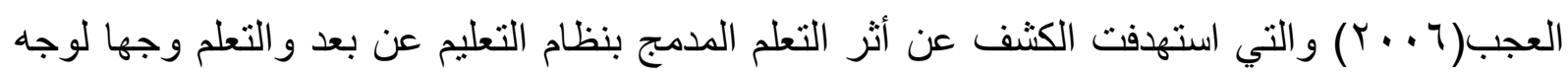

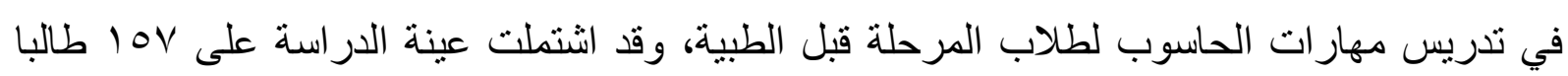


الآثار التريوية للتعليم عن بعد لاى طلاب الجامعات أثناء جائحة كورونا

(أ.د/فاطمة محمد عبد الوهاب الخليفة )

وطالبة سجلوا في مقرر مهارات الحاسوب للمرحلة قبل الطبية بجامعة الخليج العربي، وقد توصلت الدراسة الى فعالية الدمج بين التعلم الالكتروني والتعلم وجها لوجه في تنمية التحصبل والمهار ات العملية.

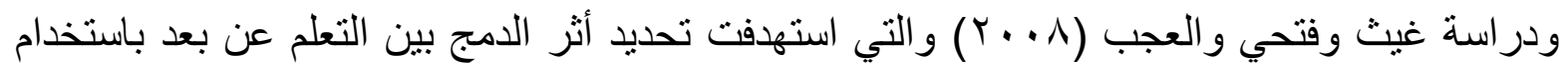
بيئة التعلم الافتر اضية WebCT و التعلم وجها لوجه على التحصيل الدراسي ورضا الطلاب عن مقرر استر اتيجيات التدريس لطلاب كلية التربية، وقد تم تكونت عينة الدراسة من وq طالبا وطالبة من طلاب كلية التربية، وقد أظهرت الدراسة الأثر الإيجابي لنظام التعلم المدمج على التحصيل الدراسي وإظهار رضا الطلاب عن مقرر استر اتيجيات التدريس.

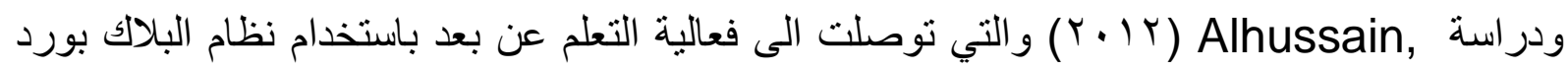
لإدارة عملية التعلم على التحصيل وبقاء أثر التعلم.

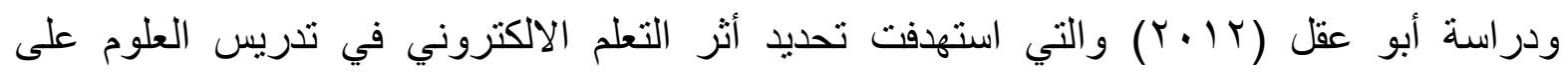
التحصيل الدر اسي لدى طلاب جامعة القدس المفتوحة المسجلين في الفصل الدراسي الثاني، وقد أسفرت الدراسة عن فروق دالة احصائيا بين أفراد المجموعة التجريبية وأفراد المجموعة الضابطة في كل الأنشطة وفي الاختبار التحصيلي لصالح المجموعة التجرييية، ولم توجد فروق دالة احصائيا بين أفراد المجمو عة التجريبية والضابطة تعزي الى متغير الجنس. دراسة عوض وأبو بكر (Y Y ( Y) والتي توصلت الى الأثر الإيجابي لنمط التعليم المدمج على تحصيل الدر اسين لمقرر التدخل في حالات الأزمات والطوارئ، في جامعة القدس المفتوحة. أما دراسة الجبر (10 ب (Y) فقد أوصت بتدريب طلاب كليات التربية على استخدام أدوات التعلم الالكتروني، و التعلم عن بعد وذلك لتحقيق أهداف تربوية محددة وذلك وفقا لدر اسة استهدفت تحديد أدوات التعلم الالكتروني التي يستخدمها طلاب التربية الأساسية في جامعة الكويت. أما در اسة الحسن (T 1 • Y) فقد توصلت الى فعالية تقنية الحوسبة السحابية في تعزيز التعلم القائم على المثاريع لدى طلاب كلية التربية جامعة الخرطوم وذلك بعد تطبيق الاختبار التحصيلي وبطاقة ملاحظة مهار ات التعلم القائم على المشروع وقد أوصى الباحث بضرورة تدريب أعضاء هيئة التدريس على كيفية توظيف تقنية الحوسبة السحابية في تدريس المقررات الجامعية. كما تناولت دراسة بباوي وتوفيق (T ( • ( ) أعدت هذه الدراسة تصور مقترح للتقويم التكنولوجي حتى يمكن تحقيق التعلم الالكتروني النشط من خلال اعداد بنوك الأسئلة متعدد المستويات في ضوء المعايير 
الآثار التريوية للتعليم عن بعد لاى طلاب الجامعات أثناء جائحة كورونا

(أ.د/فاطمة محمد عبد الوهاب الخليفة )

التربوية ، وقد اوصت هذه الدراسة بضرورة تدريب المعلمين على أساليب التقويم الالكتروني ووضع الأسئلة وتحديد مستوياتها.

وقد تناولت در اسة محمد(T 1 • Y) تحديد دور التقنية المعلوماتية في تطوير التعليم عن بعد بالجامعات السودانية، ولتحقيق هذا الهدف استخدمت المنهج الوصفي التحليلي من خلال استخدام الاستبيان كأداة رئيسة وتم التطبيق على عينة قوامها (.0) أستاذ / أستاذة تم اختيارهم عشوائيا من أساتذة الجامعات السودانية، وقد توصلت الدراسة الى ضرورة استخدام تقنيات التعلم و المعلومات في تطوير التعلم عن بعد وفقا لأسس ومبادئ التصميم التعليمي، عدم تو افر الوسائل التعليمية والمعامل بالجامعات، وكذلك ضعف ودف ونف مهار ات الطلاب في استخدام الانترنت والحاسوب مع عدم توافر الدورات التدريبية للمعلمين والتي تساعد في انتاج وتطوير المواد التعليمية مما أدى الى تجاهل ثقافة استخدام الحاسوب في العملية التعليمية، وقد أوصت الدراسة بضرورة إعداد خطة جيدة لبرنامج التعليم عن بعد لتحقيق أهداف المؤسسات التعليمية الحديثة في تسجيل وتقديم المحاضرات والاهتمام بتدريب الأساتذة على تصميم المحاضرات بصورة تلائم الطلاب، وضرورة استخدام وتطبيق تقنيات المعلومات غير المستخدمة مثل المؤتمرات عبر الفيديو كونفر انس، ومواقع التواصل الاجتماعي وتوفير متطلبات تقنية المعلومات في تطوير التعليم عن بعد؛ في حين توصلت دراسة Alhussain, 2017 إلى فاعلية التعلم عن بعد باستخدام نظام البلاك بورد على بقاء أثر التعلم.

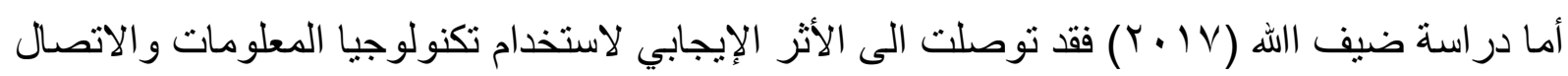
على تحسين جودة العملية التعليمية دن وجهة نظر الطلبة بالجامعات الجزائرية، في المحاور المختلفة خاصة فيما يتعلق بزيادة فهم الطلاب، وسهولة تقويم الطلاب عن بعد، وقد اوصت الباحثة بأهمية توظيف تكنولوجيا المعلومات والاتصال في تحسين جودة العملية التعليمية لدى الطلاب في الجامعات.

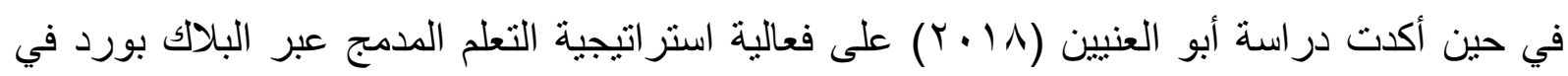
تنمية مهار ات انتاج البر امج الالكترونية وأنماط التعلم و التفكير والاتجاه نحوها لدى طالبات كلية التربية، وقد أوصى الباحث بضرورة تدريس المقررات الالكترونية التعليمية الجامعية بنظام التعليم عن بعد و التعليم المدمج، وتدريب أعضاء هيئة التدريس على ذلك. ومن ناحية أخرى حددت در اسة السيد (1 ( • ب) المعايير التربوية والفنية لتقويم مواقع الانترنت لتعليم اللغة العربية لغير الناطقين بها ، وإعداد تصور مفترح لتقويم دواقع الانترنت في ضوء هذه المعايير، ومن المعايير التربوية لمواقع التعليم عن بعد ومنها توافر المعلومات المرجعية عن المواقع التعليمية، وتحديد الأهداف التعليمية والتربوية للموقع الاكتروني، وتحديد وظائف الموقع الاكتروني وتحديد 
الآثار التريوية للتعليم عن بعد لاى طلاب الجامعات أثناء جائحة كورونا

(أ.د/فاطمة محمد عبد الوهاب الخليفة )

المحتوى التعليمي بدقة، ومر اعاة خصائص الطلاب المتعلمين والمستهدفين من التعلم عن بعد وتوظيف

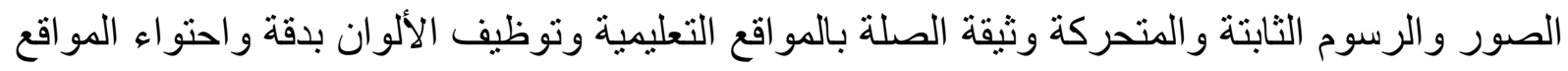
التعليمية على الروابط الفائقة وأساليب التصفح والتحديث المستمر والمتابعة للمواقع وتحقيق الأمان للمو اقع الالكترونية.

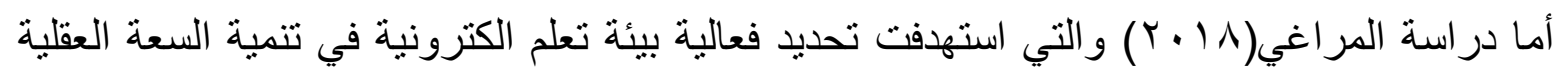
للى طلاب التعليم الثانوي الصناعي، ولتحقيق هذا الهدف تم بناء نموذج لتصميم بيئة تعلم الكترونية

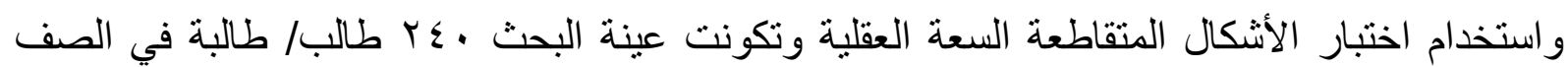
الثالث الثانوي وتوصلت الدراسة الى فعالية بيئة التعلم الالكترونية في تتمية السعة العقلية لاى الطلاب.

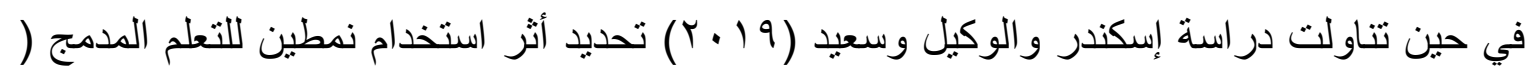
المرن- الفصل المقلوب) في تتمية بعض مهار ات برنامج الجداول الحسابية لدى طالبات المرحلة الثانوية و التجارية وذلك من خلال تطبيق اختبار تحصيلي وبطاقة ملاحظة، وقد توصلت الى فعالية التعلم المدمج في تتمية مهار ات برنامج الجداول الحسابية لدى طالبات المرحلة الثانوية. أما دراسة عبد المنعم و عبد الحفيظ و عبد العليم (9 ( ب ) و التي تناولت تحديد أثر استخدام الرحلات

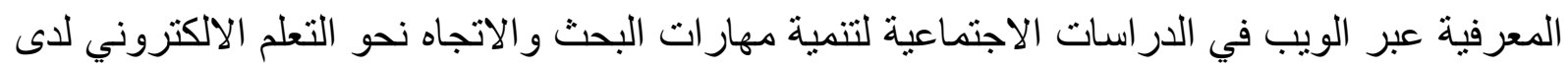
تلاميذ المرحلة الإعدادية والتي توصلت الى فعالية استخدام الرحلات المعرفية عبر الويب في تتمية مهار ات البحث والاتجاه نحو التعلم الالكتروني. كما أكدت دراسة Diab (9 (Y (Y) على فعالية التعلم عبر الانترنت لتنمية مهارات الكتابة الإبداعية و الكفاءة الذاتية لدى طلاب المرحلة الجامعية شعبة اللغة الإنجليزية. كما أكدت دراسة العطار(9 ( ب ) و التي أكدت على الدور الإيجابي للرحلات المعرفية عبر الويب في تنمية مهار ات الآداء اللغوي لدى الطلاب المعلمين شعبة اللغة العربية.

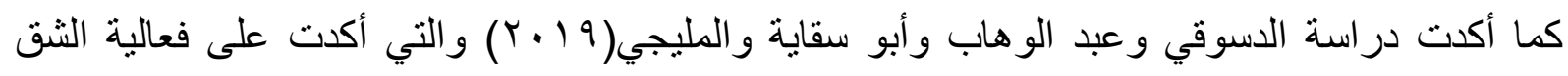
الالكتروني القائم على التعلم الذاتي في الفصل المعكوس في تتمية مهارات انتاج برمجيات الوسائط المتعددة لدى طلاب تكنولوجيا التعليم في كلية التربية النو عية.

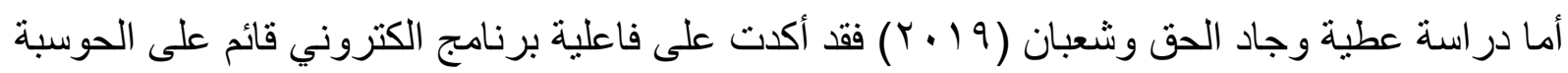
السحابية في تنمية مهار ات البرمجة لدى طلاب تكنولوجيا التعليم في كلية التربية النوعية. 
الآثار التريوية للتعليم عن بعد لاى طلاب الجامعات أثناء جائحة كورونا

(أ.د/فاطمة محمد عبد الوهاب الخليفة )

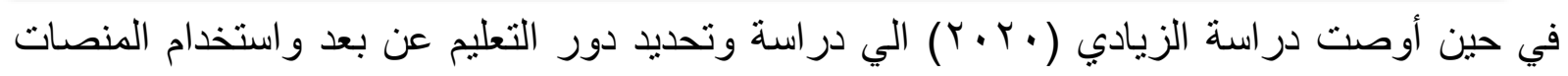
التعليمية في تنمية مهار ات التفكير عامة ومهار ات التفكير الإبداعي لدى طلاب كلية التربية الأساسي. در اسة الثمر اني والعرياني ( • • • (Y) هدف البحث إلى الكثف عن فاعلية استخدام منصات التعليم عن بعد (بو ابة المستقبل- منظومة التعليم الموحدة) في تنمية التحصيل المعرفي وخفض مستوى قلق الاختبار لدى طلاب وطالبات المرحلة المتوسطة بجدة في مادتي العلوم والدراسات الاجتماعية والمواطنة، استخدم البحث المنهج شبه التجريبي القائم على التصميم التجريبي ذو المجموعة التجريبية الواحدة- قبلي/ بعدي- وتكونت عينة البحث من ( 230) طالب وطالبة بالصف الثالث المتوسط بجدة، وقد توصلت الدراسة فاعلية استخدام منصات التعليم عن بعد في تتمية التحصيل الدراسي وخفض قلق الاختبار لدى طلاب المرحلة المتوسطة، وقد أوصى البحث بضرورة استخدام منصات التعليم عن بعد ( بوابة المستقبل- منظومة التعليم الموحدة) في التدريس و التعلم لدى الطالبات و الطلاب.

ودر اسة الفيصل ( • • • و و التي هدفت إلى إبراز أهمية ومعالم التعليم عن بعد والذي طبق ابتداءً من 22 مارس • r • r في كل مدارس وجامعات دولة الإمارات العربية المتحدة وتركز على تجربة كلية الخوارزمي الدولية، كأحد أبرز مؤسسات التعليم العالي الخاص في دولة الإمارات عن طريق إلقاء الضوء على المهار ات والتقنيات الأساسية لتلبية متطلبات التعليم عن بعد. ووصف واقع التعليم عن بعد في الإمار ات في فترة انتشار فيروس كورونا، وتفعيله بالاستتاد على منصة رقمية تسير العملية التعليمية بسلاسة من خلال التعليم الجامعي العالي في كلية الخوارزمي الدولية، وكيفية التزامها بمعابير الجودة الأكاديمية سواء من حيث إعادة تصميم المنظومة الأكاديمية المتكاملة، والضوابط ومعايير الجودة في إعادة جدولة الخطط الدرسية تماثيا مع التعليم المفتوح بالإضافة إلى ضوابط دعم وتطوير الطلاب وفي إعادة تصميم طرح المادة الدرسية في كل البر امج الأكاديمية المطروحة في كلية الخوارزمي. أما در اسة رضوان ( • · • (Y) فقد تناولت و اقع البنية التحتية الالكترونية والتعليم عن بعد في المؤسسات التعليمية وو اقع عملية التو اصل والاتصال لدى المعلمين والمتعلمين في المراحل الدر اسية، وقد توصلت النتائج الى أن •9 \% من التلاميذ ليس لديهم الرغبة أو القدرة على الاتصال أو التواصل مع الوسائط الالكترونية بأنو اعها، و • بسيطة مرتبطة بأحد الوسائط من أجل الترفيه، و٪\% لديهم معرفة الكترونية تؤهلهم لاستخدام الجيل الثالث في عملية التقويم و ب٪\% لديهم القدرة على التعامل مع الجيل الرابع وأن القياس الذكي وتقديم الارشاد، وقد اوصت الدراسة بضرورة وأهمية إعداد خطة جيدة لبرنامج التعليم عن بعد لتحقيق أهداف المؤسسات التعليمية الحديثة في تسجيل وتقديم المحاضرات والاهتمام بتدريب الأساتذة على تصميم 
الآثار التريوية للتعليم عن بعد لاى طلاب الجامعات أثناء جائحة كورونا

(أ.د/فاطمة محمد عبد الوهاب الخليفة )

المحاضرات بصورة تلائم الطلاب، وضرورة استخدام وتطبيق تقنيات المعلومات غير المستخدمة مثل المؤتمرات عبر الفيديو كونفر انس، ومواقع التواصل الاجتماعي وتوفير متطلبات تقنية المعلومات في تطوير التعليم عن بعد والتغلب على الصعوبات التي تواجه التطبيق والاهتمام بشبكة الاتصال وتقويتها على مستوى السودان مع توفير الوسائط و المعدات الحديثة للتعليم عن بعد. مما سبق يتضح أن بعض الدراسات السابقة استهدفت تحديد أدوات التعلم الالكتروني التي يستخدمها الطلاب وو اقع استخدام طلاب الجامعات لها، كما استهدفت بعض الدراسات الأخرى تحديد فعالية التعلم الالكتروني والتعليم عن بعد في تحقيق بعض المخرجات التعليمية مثل التحصيل ومهارات التفكير، ومهارات انتاج برمجيات الوسائط المتعددة، ومهارات البحث والاتجاه نحو التعلم الالكتروني تنمية مهار ات برنامج الجداول الحسابية، وخفض قلق الاختبار، كما استهدفت بعض هذه الدراسات تحديد متطلبات التعليم عن بعد، والتعلم الاكتروني وواقع البنية التحتية في تفعيل التعليم عن بعد، وقد تم تطبيق بعض هذه الدراسات على تلاميذ المرحلة الابتدائية والإعدادية والمتوسطة، وطلاب المرحلة الثانوية، وطلاب المرحلة الجامعية، وقد أوصت هذه الدر اسات بضرورة اتاحة البنية التحتية اللازمة لتفعيل التعليم عن بعد، وتتبع ودر اسة الآثار التعليمية والتربوية للتعلم عن بعد، و التعلم المدمج على الطلاب بمر احل التعليم المختلفة.

مشكلة الدراسة:

شهدت الجامعات المصرية تطورا ملحوظا في استخدام نظام التعليم عن بعد لتدريس وتعلم المقررات الجامعية للطلاب خاصة منذ بداية ظهور و انتشار جائحة كورونا لما لهذا النظام من خصائص ومميز ات من أهمها أنه لا يتطلب الخروج من المنازل وسهولة نوظيف الإمكانات الهائلة له، والتفاعل الفردي، وحسن استثمار الوقت والجهد وتحقيق مبدأ الفروق الفردية، وسرعة وسهولة الاتصال الفعال بين الأستاذ والطالب، وتحقيق الإدارة الفعالة لعملية التعليم؛ حيث يتولى المعلم مسئولية الإشراف على الجانب التعليمي والعلمي وضمان حسن سير العملية التعليمية، كما يتولى مسئولية اعداد المقررات الدراسية وتتظيمها وتسجيلها ونشر ها للطلاب ويتابع مدى تقدمه ومتابعة تعلمهم ومناقثة استفسار اتهم والاجابة عنها وتوجيه الطلاب للبحث والاستقصاء حول هذه الأسئلة واعداد تقارير مناسبة لها ورفعها للمعلم لتقييمها؛ في حين يتولى الطالب دراسة المقررات الاككترونية، و التفاعل معها، والتعليق عليها وتسجيل الاستفسار ات والتساؤلات بشأنها والبحث حولها وتلخيص ما يتعلق بالإجابة عن هذه الأسئلة والتفاعل المثمر مع المعلم بشأنها، والتو اصل الالكتروني الفعال مع الزملاء. 
الآثار التريوية للتعليم عن بعد لاى طلاب الجامعات أثناء جائحة كورونا (أ.د/فاطمة محمد عبد الوهاب الخليفة )

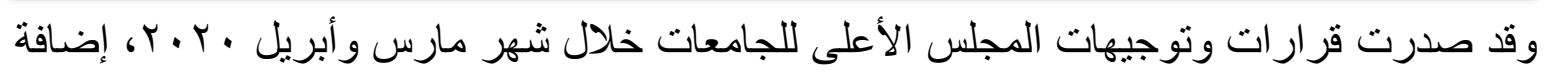

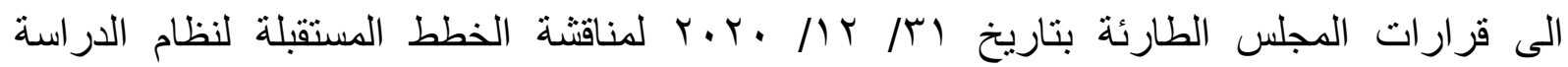

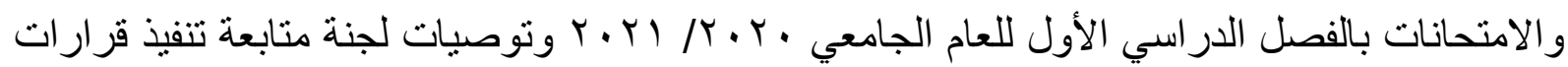

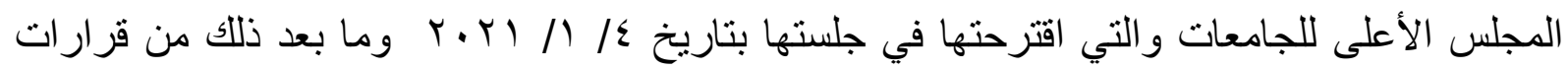
وتوجيهات بضرورة استكمال تدريس / تعلم جميع المناهج و المقررات الدراسية الجامعية بنظام التعليم

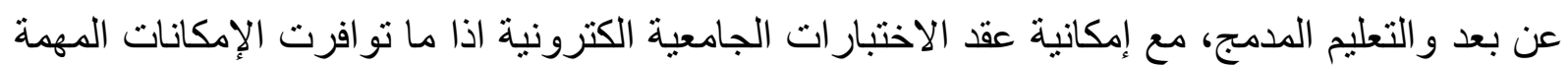
و اللازمة لذلك.

وبناء على ذللك فقد تم التوجيه للجامعات والكليات بضرورة تحويل المناهج الدراسية والدقرر ات المختلفة

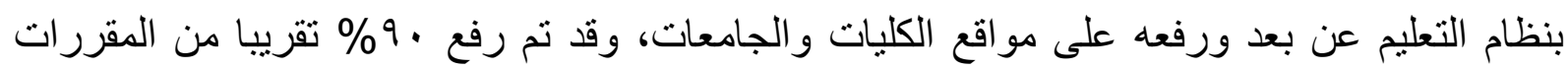

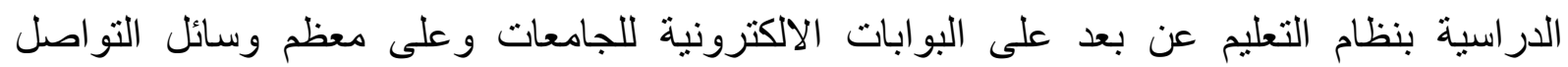

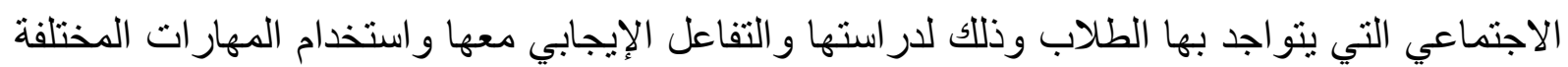

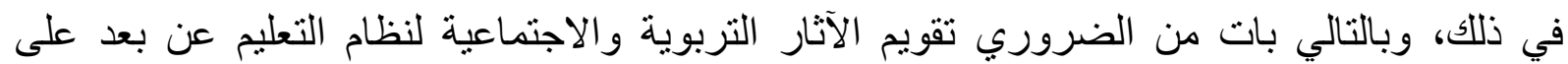
الطالب الجامعي. وقد رفعت جامعة بنها جميع مقررات المرحلة الجامعية الأولى والدراسات العليا تقريبا وبنسبة 90\% وكان عدد المقررات المرفوعة تزيد عن ألفين مقرر من جميع كليات الجامعة وبرامجها ومقرراتها،

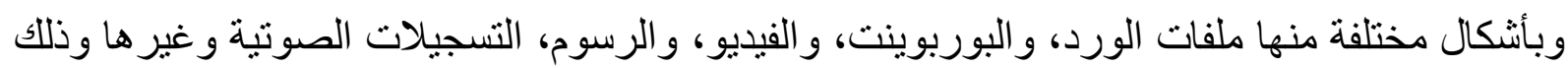

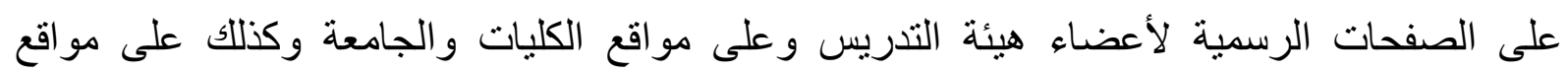

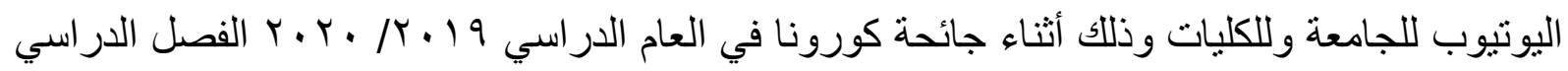

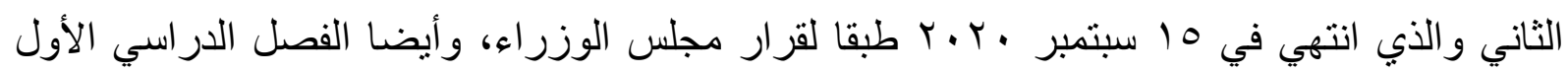

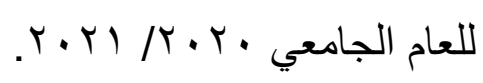

وقد أجريت العديد من الدراسات والبحوث حول مزايا وفوائد التعليم عن بعد والتعليم الدمجج

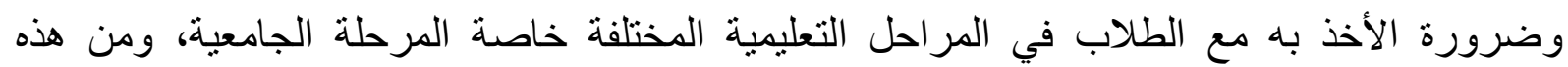

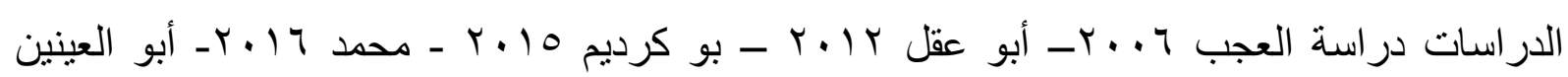

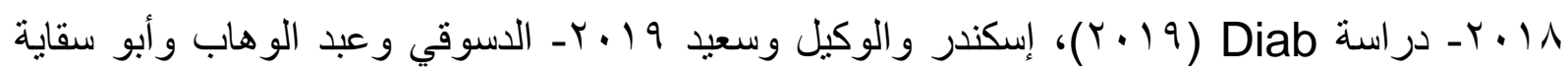

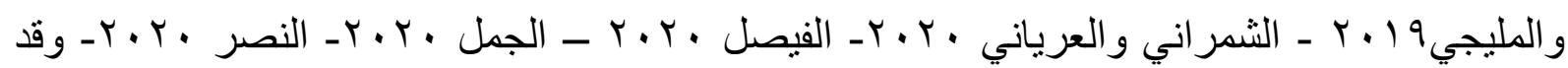
أوصت هذه الدراسات باستخدام نظام التعليم/التعلم عن بعد وتوظيف استر اتيجياته في تدريس المقررات 
الآثار التريوية للتعليم عن بعد لاى طلاب الجامعات أثناء جائحة كورونا

(أ.د/فاطمة محمد عبد الوهاب الخليفة )

الدراسية في المرحلة الجامعية وما قبلها وأيضا بضرورة تحديد الآثار المختلفة لها وتقييم المخرجات التعليمية التي تنتج عن استخدامها لدى الطلاب.

كما أصدر معهد التخطيط القومي دراسة بحثية بعنوان البنية التحية التكنولوجية و التحول الرقمي و أدواره

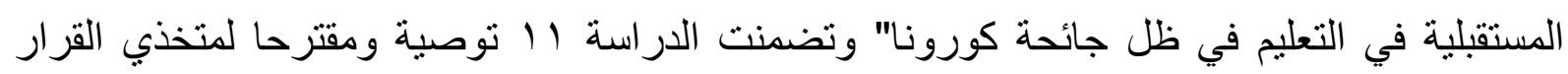
يمكن أن تساعد على تطوير التعليم في مصر في ظل فلئ الأزمة الحالية. ومن أهم التوصيات المتعلقة بالتعليم عن بعد في الجامعات منها:

ا. العمل على ربط الجامعات المصرية بشبكة اتصال موحد وربط الكليات المناظرة في كل الجامعات بشبكات انترنت فيما بينها وذلك لتبادل الخبر ات و المعلومات.

r. إنشاء وتحديث البنية التحنية في الجامعات المصرية تمهيدا للتحول نحو التعليم عن بعد. r. التوسع في استخدام تكنولوجيا المعلومات في التعليم عن بعد في الجامعات و المعاهد.

ومن مظاهر الاهتمام أيضا بالتعليم عن بعد والتعليم المدمج خاصة أثناء جائحة كورونا فقد أجريت بعض

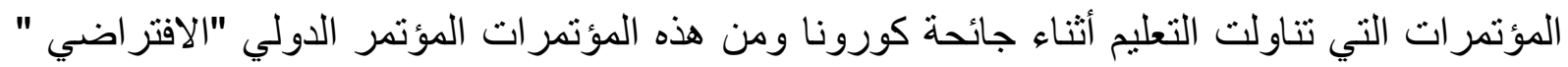

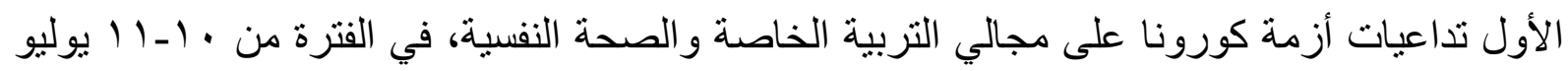

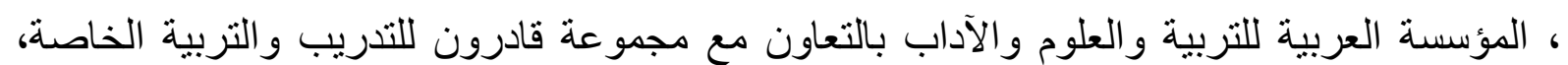

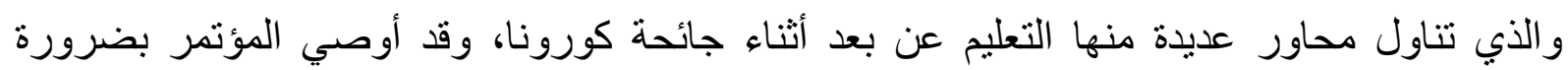
التوسع في استخدام التعليم عن بعد خاصة في الفترة القادمة، مع التقييم المستمر لهذا على المخرجات التعليمية المتنو عة لاى الطلاب.

كما أقيم المؤتمر الافتراضي الدولي فيروس كورونا المستجد ـ تحديات وممارسات متعددة التخصصات

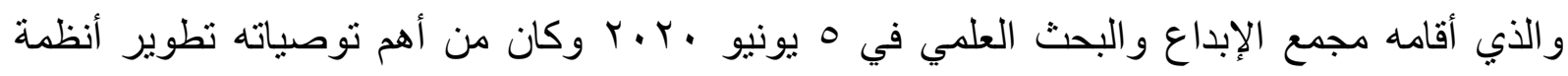

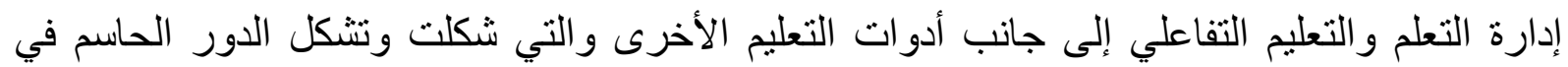
نظام التعليم الجامعي في الفترة القادمة تو اكبا مع مقتضيات الأوضاع الصحية والاجتماعية والتعليمية. كما عقد اتحاد الأكاديميين والعلماء العرب في شهر أكتوبر •r.Y.r. مؤتمر عبر الإنترنت بعنوان

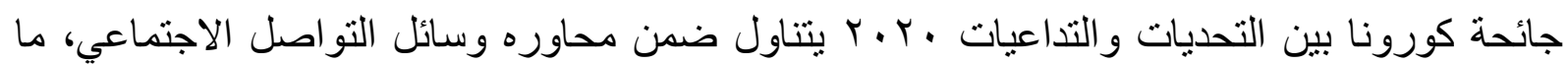

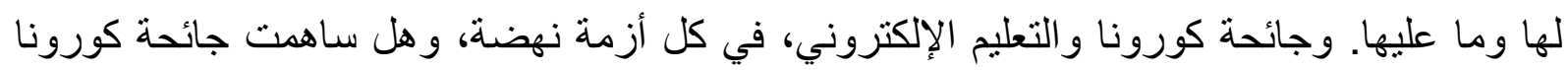

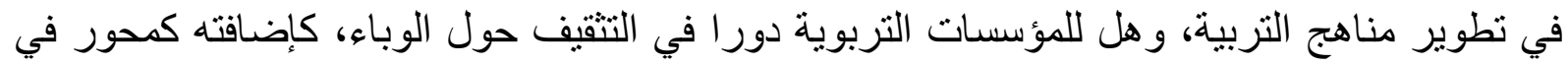

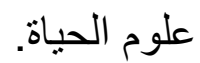


الآثار التريوية للتعليم عن بعد لاى طلاب الجامعات أثناء جائحة كورونا

(أ.د/فاطمة محمد عبد الوهاب الخليفة )

كما عقدت أكاديمية رواد التميز للتعليم والتدريب والاستشارات والتتمية البشرية المؤتمر الخامس و المعنون " التعلم الرقمي في الوطن العربي (و اقعه، تحديات، أفاقه المستقبلية) فيما بعد كورونا والمنعقد

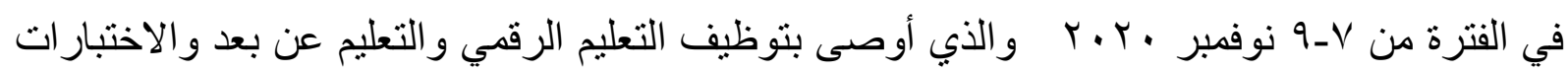
الالكترونية واجر اء دراسات حول تأثير التعليم عن بعد على الطلاب وتحديد الآثار المختلفة للتعلم عن بعد على الطلاب. ومن هذا المنطلق ظهرت مشكلة الدراسة في ضرورة تقصي وتقييم الآثار التربوية للتعلم عن بعد أثناء جائحة كورونا لاى طلاب الجامعات، وللتصدي لهذه المشكلة حاولت الاراسة

\section{الحالية الإجابة عن التساؤلات الآثية:}

ا ـ ما أثنكال التعليم عن بعد التي تم استخدامها في تدريس المقررات الدراسية في الجامعات أثناء

$$
\text { جائحة كورونا؟ }
$$

r- ما الآثار التربوية لاستخدام التعليم عن بعد أثناء جائحة كورونا على طلاب الجامعات من وجهة

$$
\text { نظر هم? }
$$

بـ ما دلالة الفروق الإحصائية بين متوسط درجات طلاب الجامعات عن الآثار التربوية للتعلم عن

$$
\text { بعد و التي ترجع لمتغير الجنس؟ }
$$

عـ ما دلالة الفروق الإحصائية بين متوسط درجات طلاب الكليات عن الآثار التربوية للتعلم عن بعد

$$
\text { و التي ترجع الى التخصص (التربوية ـ الطبية- الهندسية ـ العلوم الأساسية)؟ }
$$

هـ ما دلالة الفروق الإحصائية بين متوسط درجات طلاب الجامعات عن الآثار التربوية والتي ترجع الى الفرقة الدر اسية (الأولىـ الثانية ـ الثالثة ــ الر ابعة ـ الخامسة ـالدر اسات العليا)؟

\section{أهداف الاراسة وأهميتها:}

1. تحديد أثكال التعليم عن بعد التي تم استخدامها في تدريس المقررات الدراسية في الجامعات أثناء جائحة كورونا، مما بساهم في ترسيخ ثقافة ومفهوم التعليم عن بعد كمتغير مؤثر و عامل فعال في استكمال الدراسة الجامعية، وكذللك تطوير العملية التعليمية وتوصيفات البرامج و المقررات و إلقاء الضوء على التطورات السريعة والمتلاحقة للتكنولوجيا المتطورة واستخدامها في التعليم الجامعي. r. توضيح الآثار التربوية لاستخدام التعليم عن بعد أثناء جائحة كورونا على طلاب الجامعات، مما ينعكس على تتمية وعي أعضاء هيئة التدريس والطلاب بنظام التعليم عن بعد و إمكانية استخدامه 
الآثار التريوية للتعليم عن بعد لاى طلاب الجامعات أثناء جائحة كورونا (أ.د/فاطمة محمد عبد الوهاب الخليفة )

في تحقيق أهداف محددة، وبالتالي مر اعاة مخرجات التعليم المختلفة التي يمكن أن يحققها عند استخدامه في التعليم الجامعي. r. تحديد دلالة الفروق بين متوسطات درجات الطلاب في الآثار التربوية لاستخدام التعليم عن بعد والتي قد ترجع الى الجنس، مما بساهم في تحديد الفروق بين هذه الآثار على الطلاب و الطالبات، وتحديد أشكال و أنماط التعليم عن بعد والتي يفضلها كل جنس ويمكن استخدامها في تدريس وتعلم المقررات الأكاديمية في المرحلة الجامعية، وبالتالي تدريب أعضاء هيئة التدريس على ذلك. ع. تحديد دلالة الفروق بين متوسطات درجات الطلاب في الآثار التربوية لاستخدام التعليم عن بعد و التي قد ترجع الى التخصص (المجموعة التربوية ـ المجموعة الطبية- المجموعة الهندسية ـ مجموعة العلوم الأساسية)، وتحديد الخصائص المميزة لأنماط التعليم عن بعد والمفضلة من قبل بعض القطاعات و التخصصات في كليات الجامعة، وبالتالي مر اعاة هذه الخصائص في التعليم عن بعد عند استخدامها مع الطلاب. •. تحديد دلالة الفروق بين متوسطات درجات الطلاب في الآثار التربوية لاستخدام التعليم عن بعد قد ترجع للفرقة الدراسية، مما يساهم في تتوع أساليب وأنماط التعليم عن بعد والتي يتم نوظيفها مع الطلاب في الفرق الدر اسية المختلفة.

حدود الدراسة: التزمت الدراسة الحالية بالحدود الآتية:

ا. تطبيق الاستبيان على عينة من طلاب وطالبات المرحلة الجامعية الأولى والدراسات العليا في كليات جامعة بنها و عددها 10 كلية كعينة لطلاب الجامعات الحكومية. r. تحديد الآثار التربوية للتعلم عن بعد على طلاب الجامعات في خمسة أبعاد وهي: (مهار ات التفكير للى الطلاب، التحصيل الأكاديمي لدى الطلاب، مهارات التعلم الذاتي لدى الطلاب، الدافعية الذاتية للتعلم لدى الطلاب، المهارات الاجتماعية لدى الطلاب) كون هذه الأبعاد تعكس أهم نو اتج تعلم البر امج المختلفة وتعكس أيضا الثناث جو انب المهمة للتعلم (الجوانب المعرفية ـ الجو انب المهارية - الجو انب الوجدانية). 


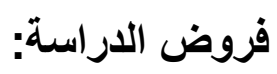

اـ درجة الموافقة على الآثار التربوية للتعلم عن بعد على طلاب الجامعات كانت مرتفعة من وجهة نظر هم وذلك في الأبعاد الخمس للاستبيان وفي درجة الاستبيان ككل

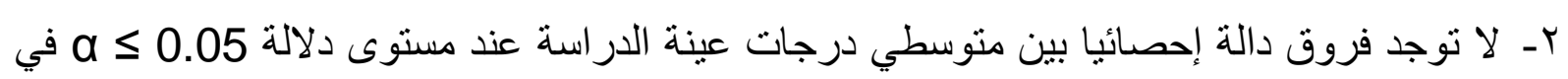
الاستبانة ككل وكذللك في كل محور من محاور ها الخمسة تبعاً لمتغير الجنس.

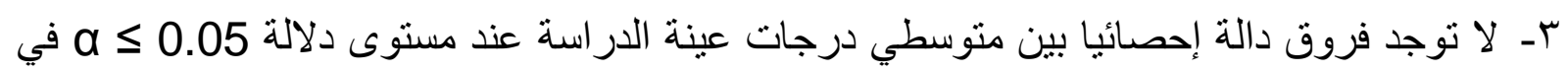

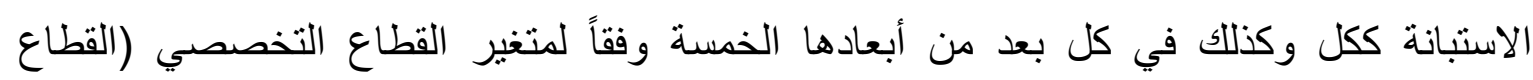
التربوي - قطاع العلوم الأساسية ـ القطاع الطبيـ قطاع العلوم الهندسية).

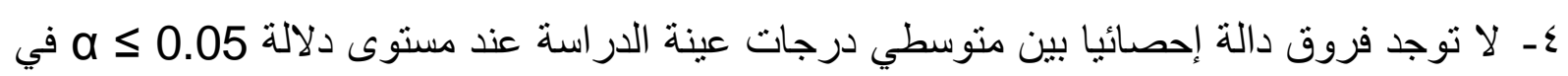

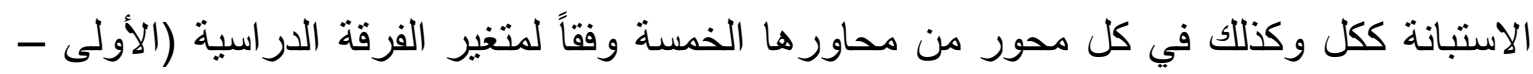

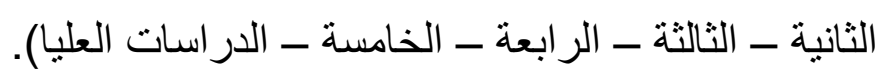

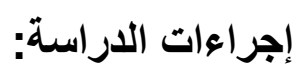

أو لا: تحديد أثنكال التعليم عن بعد المستخدمة أثناء جائحة كورونا لتدريس المقررات الجامعية.

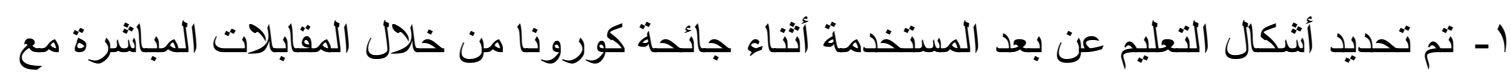

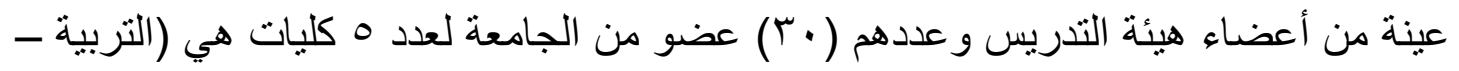

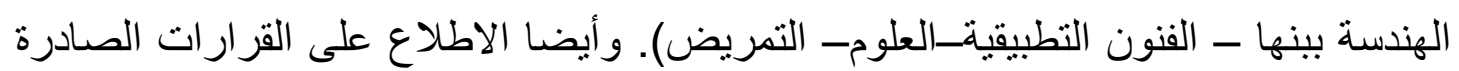

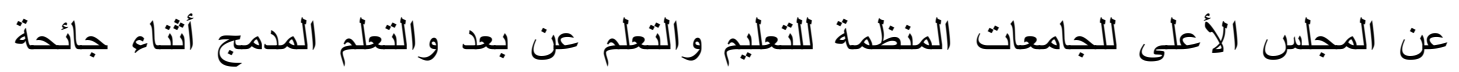

$$
\text { كورونا و التي نففتها والتزمت بها الجامعات المصرية. }
$$

r- تم التوصل الى الصورة المبدئية لأشكال التعليم عن بعد والتي تم استخدامها أثناء جائحة

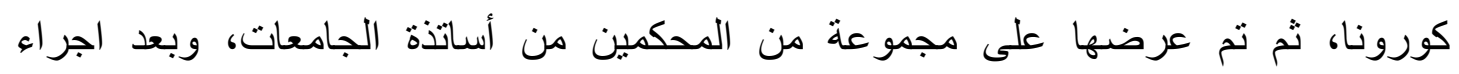

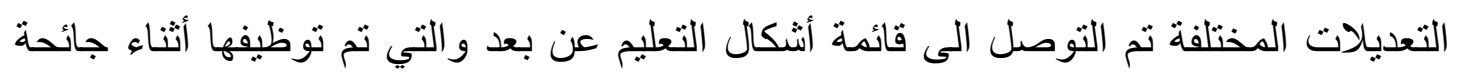

$$
\text { كورونا. }
$$

ثانيا: تحديد الآثار التربوية للتعلم عن بعد على طلاب الجامعات وقد تم ذلك من خلال اعداد استبيان

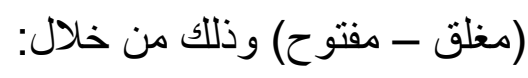

$$
\text { r ا ـ الاطلاع على البحوث و الدر اسات السابقة ذات الصلة. }
$$

rـ- استبيان مفتوح لبعض أعضاء هيئة التدريس وبعض الطلاب عن الآثار التربوية للتعلم عن بعد بـ

$$
\text { على الطلاب من وجهة نظر هم. }
$$


الآثار التريوية للتعليم عن بعد لاى طلاب الجامعات أثناء جائحة كورونا

(أ.د/فاطمة محمد عبد الوهاب الخليفة )

عـ في ضوء هذه المصادر تم التوصل إلى الأبعاد الخمسة للآثار التربوية للتعلم عن بعد على طلاب

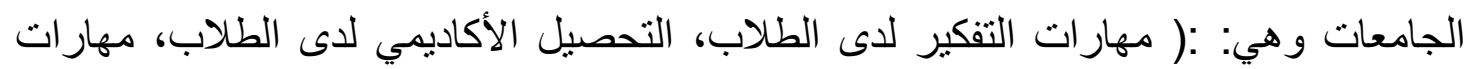
التعلم الذاتي لدى الطلاب، الدافعية الذاتية للتعلم لدى الطلاب، المهارات الاجتماعية لدى الطلاب). هـ إعداد استبيان قياس الآثار التربوية للتعليم عن بعد لدى الطلاب؛ حيث تم تحديد عدد من العبار ات التي تغطي كل بعد من هذه الأبعاد، كما تم وضع سؤال مفتوح بعد كل بعد من الأبعاد لإتاحة الفرصة للطلاب لكتابة ما يرونه مناسبا من آثار التعليم عن بعد عليهم.

7- تم وضع الأبعاد والعبار ات التي تتدرج تحتها على طريقة ليكرت أمام مقياس متدرج خماسي (

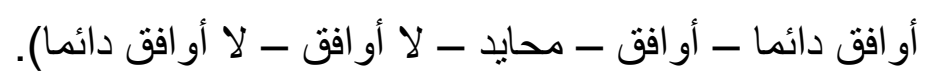
V- تحديد صدق الاستبيان: تم عرض الاستبيان في صورته الأولية على عينة من المحكمين من أعضاء هيئة التدريس في كلية التربية وكلية الآداب جامعة بنها لتحديد مدى دقة الأبعاد، ودقة

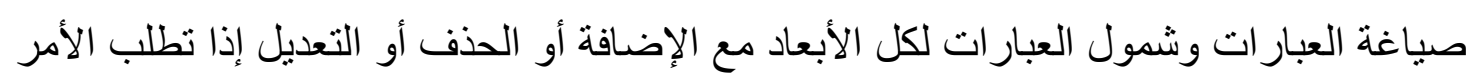

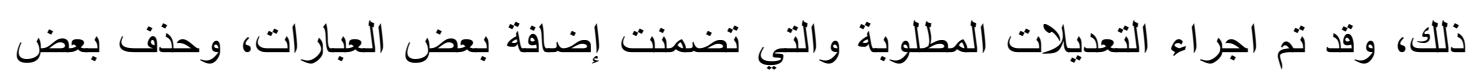
العبار ات لتكر ار ها، وتعديل صياغة بعض اهبه العبار ات الأخرى. ^- تحديد الصورة النهائية للاستبيان: تم تحديد الصورة النهائية للاستبيان والتي اشتملت على أولا: البيانات الأساسية وهي الاسم(اختياري) والجنس و الكلية و الفرقة؛ ثانيا: خمسة أبعاد والعبار ات

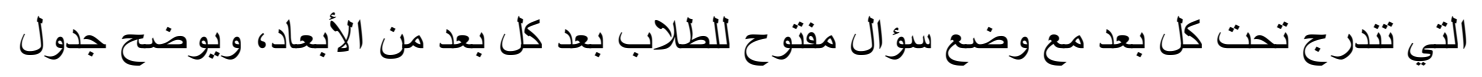

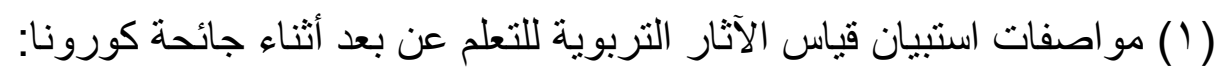

جدول (1) مواصفات استبيان الآثار التربوية للتعلم عن بعد على طلاب الجامعات

\begin{tabular}{|c|c|c|c|}
\hline النسبة \% & عدد بنود كل بعد & أرقام البنود & أبعاد الآثار التربوية \\
\hline YA.OV & Ir & من | & مهارات التفكير لاى الطلاب \\
\hline 19.0 & $\Lambda$ & 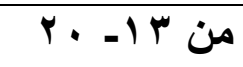 & التحصيل الأكاديمي لاى الطلاب \\
\hline$r 1 . \varepsilon r$ & 9 & من ا Y-Yq & مهارات التعلم الذاتي لاى الطلاب \\
\hline $17.7 \mathrm{~V}$ & $\mathrm{~V}$ & من · & الدافعية الأتية للتعلم لاى الطلاب \\
\hline $1 \varepsilon . Y \wedge$ & 7 & من & المهارات الاجتماعية لاى الطلاب \\
\hline$\% 1 \ldots$ & $\varepsilon r$ & r & 0 أبعاد \\
\hline
\end{tabular}

9- تم برمجة الاستبيان على https://www.google.com/forms و إعطاء الطلاب - عينة الدر اسةـ اللينك للإجابة عن الاستبيان، وذللك في جميع كليات جامعة بنها. 
الآثار التريوية للتعليم عن بعد لدى طلاب الجامعات أثناء جائحة كورونا

ثالثا: اختيار عينة الدراسة: تم اختيار عينة من جميع كليات جامعة بنها (10 كلية) ويوضح جدول (r) مواصفات العينة من الكليات و القطاعات الأربع (التربويةـ الطبية ـ الهندسيةـ العلوم الأساسية) التي تم تطبيق الاستبيان عليها:

جدول(r)

مواصفات العينة من الكليات والقطاعات الأربع (التربويةـ الطبية ــ الهندسيةـ العلوم الأساسية)

\begin{tabular}{|c|c|c|c|c|}
\hline النسبة \% & العدد & القطاعات & الكلية & r \\
\hline \multirow{3}{*}{$\% \mu \wedge . q \mu$} & \multirow{3}{*}{ rqr } & \multirow[t]{3}{*}{ المجموعة التربوية } & التربية & 1 \\
\hline & & & التربية النوعية & $r$ \\
\hline & & & التربية الرياضية & $r$ \\
\hline \multirow{3}{*}{$\% 19 . \wedge 7$} & \multirow{3}{*}{$1 \leqslant 9$} & \multirow[t]{3}{*}{ المجموعة الطبية } & الطب البشري & $\varepsilon$ \\
\hline & & & التمريض & 0 \\
\hline & & & الطب البيطري & 7 \\
\hline \multirow{4}{*}{$\% \backslash \wedge .9 \mu$} & \multirow{4}{*}{$1 \leqslant r$} & \multirow{4}{*}{ المجموعة المندسية } & الهندسة بينها & V \\
\hline & & & الـندسة بشبرا & $\Lambda$ \\
\hline & & & الحاسبات & 9 \\
\hline & & & القنون التطبيقية & 1. \\
\hline \multirow{5}{*}{$\%$ \% } & \multirow{5}{*}{$19 V$} & \multirow[t]{5}{*}{ العلوم الأسـاسية } & الحقوق & 11 \\
\hline & & & الآداب & Ir \\
\hline & & & العلوم & ir \\
\hline & & & الزراعة & $1 \varepsilon$ \\
\hline & & & التجارة & 10 \\
\hline$\% 1 \ldots$ & Vo. & ع قطاعات & 10 & \\
\hline
\end{tabular}


الآثار التريوية للتعليم عن بعد لدى طلاب الجامعات أثناء جائحة كورونا (أ.د/فاطمة محمد عبد الوهاب الخليفة )

\section{ويوضح جدول (rّ) عينة الدراسة من الذكور والإناث:}

جدول (r) مواصفات عينة الدراسة من الأكور والإناث

\begin{tabular}{|c|c|c|}
\hline النسبة & العدد & r \\
\hline$\varepsilon 7.7 V$ & ro. & الأكور \\
\hline OM.MT & $\varepsilon \ldots$ & الإناث \\
\hline$\% 1 \ldots$ & Vo. & المجموع \\
\hline
\end{tabular}

كما يوضح جدول (؛ ) مواصفات عينة الاراسة من الفرق الاراسية المختلفة في المرحلة الجامعية الأولى و الاراسات العليا

\begin{tabular}{|c|c|c|c|c|c|c|c|}
\hline المجموع & الار اسات & الخامسة & الرابعة & الثالثة & الثانية & الأولى & الفرقة \\
\hline Vo. & $\varepsilon$. & ו & rr. & 191 & $1 \% 9$ & $10 Y$ & العدد \\
\hline$\% 1 \ldots$ & $0 . \mu r$ & $\varepsilon .1 \%$ & $r \cdot .7 V$ & YI. EV & $1 \Lambda .1 \mathrm{H}$ & $r \cdot . r V$ & النسبة \\
\hline
\end{tabular}

رابعا: تم تطبيق الاستبيان بعد الانتهاء من الدراسة وفقا لقرار المجلس الأعلى للجامعات وذلك في الفترة

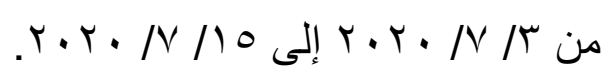

خامسا: تم معالجة الدرجات الخام للنطبيق احصائيا باستخدام المتوسطات والانحر افات المعيارية ، واختبار "ت"، واختبار (ANOVA)، اختبار شافيه Scheffe من خلال البرنامج الاحصائي SPSS.

$$
\text { نتائج الدراسة: }
$$

ا- ـ للإجابة عن السؤال الأول من أسئلة الدراسة "ما أثكال التعليم عن بعد التي تم استخدامها في

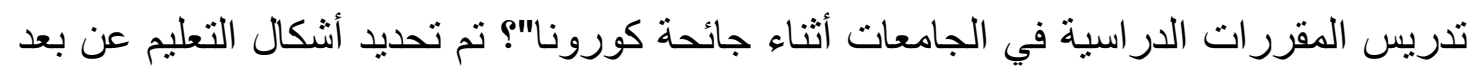
وهي التعليم المتزامن والذي يتطلب تواجد كل من المعلم والطلاب والتفاعل عبر شبكة

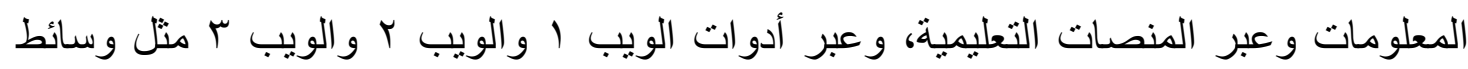

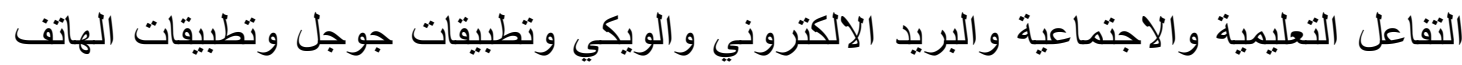

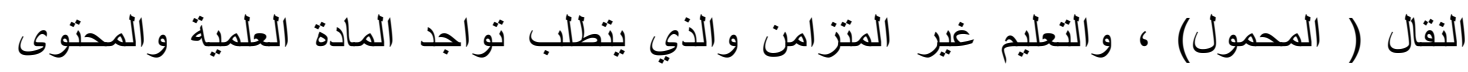

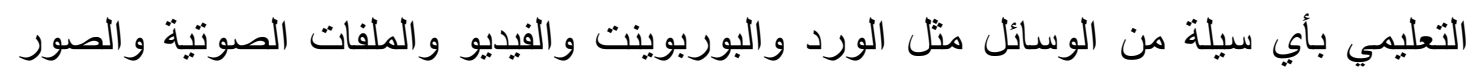

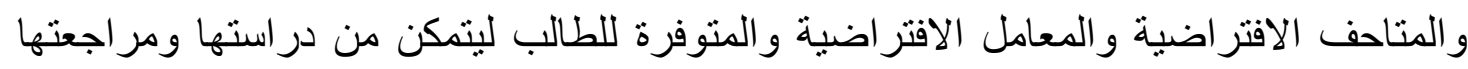


الآثار التريوية للتعليم عن بعد لاى طلاب الجامعات أثناء جائحة كورونا

(أ.د/فاطمة محمد عبد الوهاب الخليفة )

وفقا لظروفه وقدراته، وتتفق نتائج هذه الدراسة مع نتائج دراسة كل من الجبر ، 10 . ب-

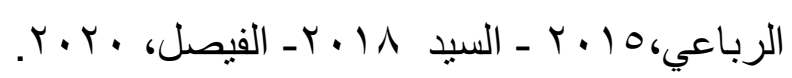

ץ- للإجابة عن السؤال الثاني من أسئلة الدراسة وهو" ما الآثار التربوية لاستخدام التعليم عن بعد أثناء جائحة كورونا على طلاب الجامعات من وجهة نظر هم؟ وللتحقق من صحة الفرض الأول من فروض الدراسة وهو" درجة الموافقة على الآثار التربوية للتعلم عن بعد على طلاب الجامعات كانت مرتفعة من وجهة نظرهم وذلك في الأبعاد الخمس للاستبيان وفي درجة الاستبيان ككل".

تم تحديد درجة موافقة عينة البحث على الاستبانة ككل و على كل بعد من أبعادها وفقا للخطو ات الآتية: - - المدى الكلى = أعلى وزن نسبى - أقل وزن نسبى. $\frac{-}{5}=$ - تم تصحيح الاستجابات وفقاً لمقياس ليكرت الثلاثي على النحو التالي: لا أوافق دائما لا أوافق محايد أوافق أوافق دائما 1 $r$

- لذا تم الحكم علي درجة مواققة أراء العينة وفق مقياس ليكرت المفسر لاستجابات عينة البحث و الموضح في الجدول الآتي:

جدول (0) مقياس دلالة المتوسط الحسابي

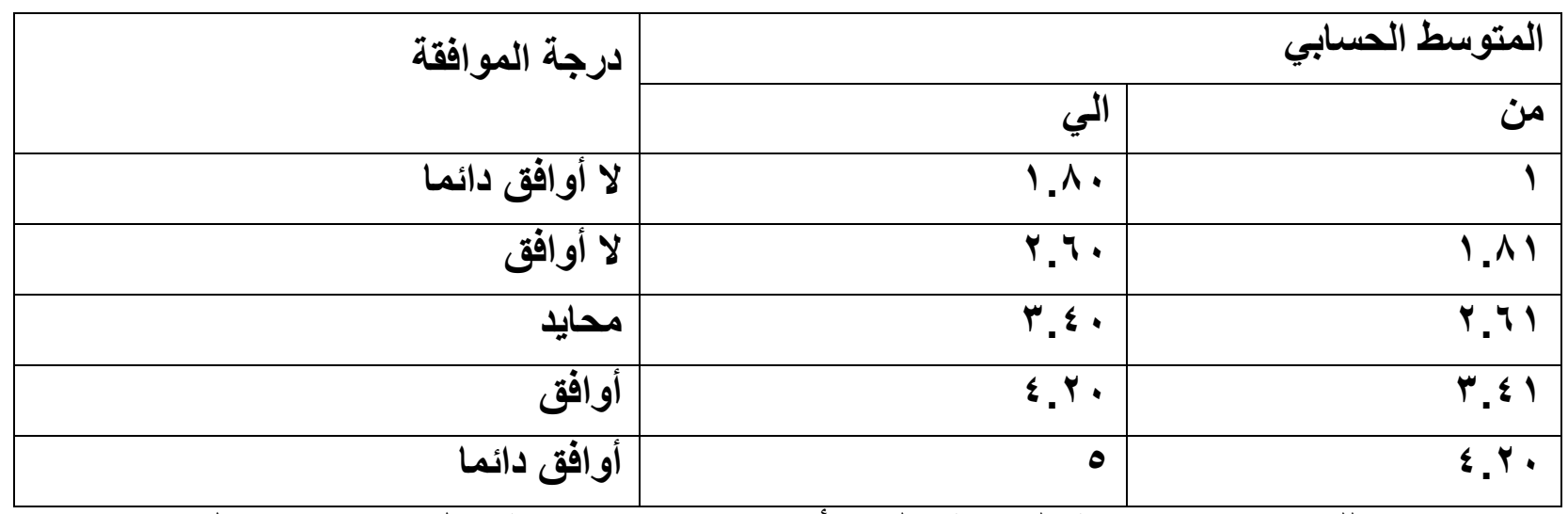

وفي ضوء ذلك تم حساب درجة الموافقة على الأبعاد اجمالا والاستبانة ككل ويوضح جدول (T) هذه 
الآثار التريوية للتعليم عن بعد لاى طلاب الجامعات أثناء جائحة كورونا

جدول (7) (7) (9)

داجة الموافقة علي الأبعاد اجمالا والاستبانة ككل (من وجهة نظر عينة الاراسة) (ن = . ل

\begin{tabular}{|c|c|c|c|c|c|}
\hline الموافقة & المئوية & الانحراف & الحسابي & المؤشرات & المحاور \\
\hline محايد & \%rr.r. & $\because 90$ & $r .17$ & ir & الأثار التربوية للتعلم عن بعد على التفكير لدى الطلاب \\
\hline محايد & $\%\ulcorner\leqslant . \wedge$. & $1 .$. & T.Y & $\wedge$ & التحصيل الأكاديمي للاى التربوية للتعليم عن بعد على \\
\hline محايد & \%TV.A. & r & $r . r q$ & 9 & 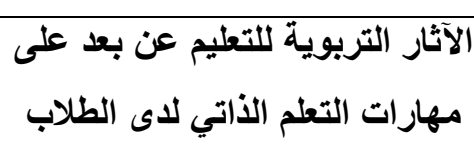 \\
\hline محايد & \%тr.A. & .90 & r. $1 \leqslant$ & v & 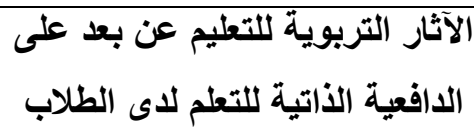 \\
\hline محايد & $\%$ \%r & $.9 v$ & r.l. & 7 & المهارات الاجتماعية لآى التربوية للتطليم عن بعد على \\
\hline محايد & \%पะ. & .91 & r.YI & $\varepsilon r$ & الاستبانة ككل \\
\hline
\end{tabular}

وبالتالي برفض الفرض الأول من فروض الدراسة وهو" درجة الموافقة على الآثار التربوية للتعلم عن

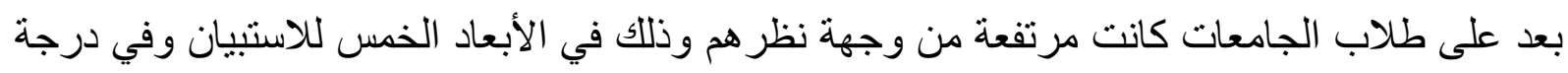

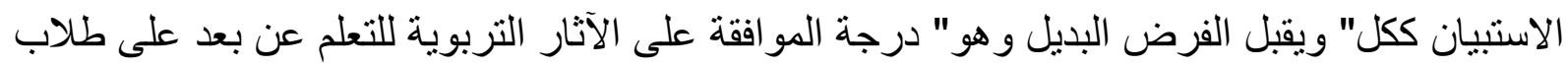

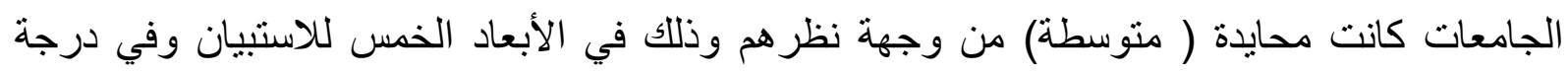

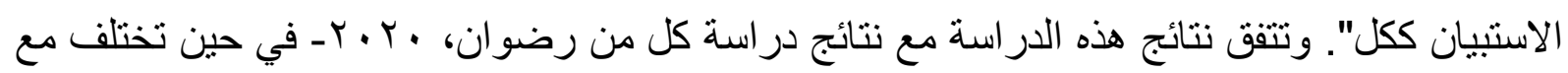

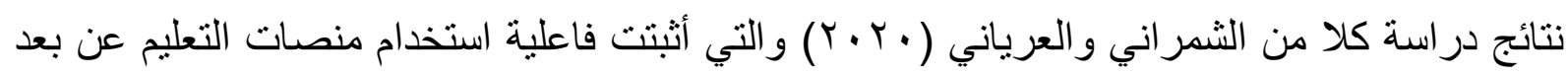
في تنمية التحصيل الدراسي وخفض قلق الاختبار لاى طلاب المرحلة المتوسطة، ودراسة ضيف الله

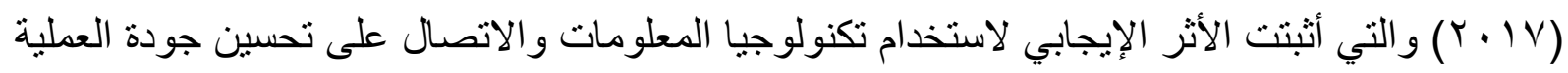

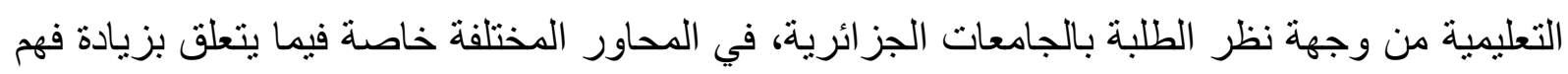

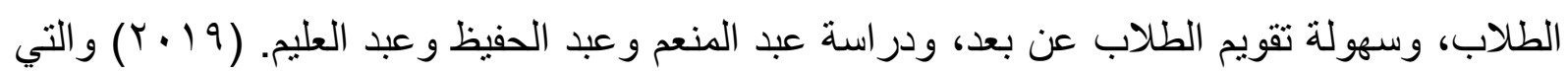


الآثار التريوية للتعليم عن بعد للى طلاب الجامعات أثناء جائحة كورونا

(أ.د/فاطمة محمد عبد الوهاب الخليفة )

الأثر الإيجابي لاستخدام الرحلات المعرفية عبر الويب في الدراسات الاجتماعية لتنمية مهارات البحث و الاتجاه نحو التحلم الالكتروني لدى تلاميذ المرحلة الإعدادية،

r- لإجابة عن السؤال الثالث من أسئلة الدراسة" ما دلالة الفروق الإحصائية بين متوسط درجات طلاب الجامعات عن الآثار التربوية للتعلم عن بعد والتي ترجع لمتغير الجنس؟" وللتحقق من صحة الفرض الثاني: لا توجد فروق دالة إحصائيا بين متوسطي درجات عينة الدراسة عند مستوى دلالة 0.05 a في الاستبانة ككل وكذللك في كل محور من محاور ها الخمسة تبعاً لمتغير الجنس.

لاختبار صحة الفرض الثاني تم حساب اختبار (ت) لعينتين مستقلتين لحساب الفرق بين متوسطي درجات أفراد العينة وفقاً لمتغير الجنس في الاستبانة ككل وفي كل محور من محاورها الخمسة، وظهرت النتائج كما هو موضح بالجدول الآتي:

\section{جدول (V)}

"قيمة " ت " لالالة الفروق بين متوسطي درجات أفراد العينة وفقاً لمتغير الجنس في الاستبانة ككل وفي أبعادها الخمسة

\begin{tabular}{|c|c|c|c|c|c|c|c|}
\hline |لدسثوى & الحرجة & قيمة (ت) & الإنحراف & المتوسط & العدد & النوع & ماور \\
\hline \multirow{2}{*}{.$\cdot 1$} & \multirow{2}{*}{$V \leqslant \Lambda$} & \multirow{2}{*}{$r . r \wedge q$} & 19.49 & $r q . Y 0$ & $r \ldots$ & ذكر & \multirow{2}{*}{ بالأثار التربوية للتعلم عن مهار } \\
\hline & & & 11.21 & $\varepsilon Y . T_{0}$ & $\leqslant 0$. & & \\
\hline \multirow{2}{*}{.1} & \multirow{2}{*}{$V \leq \Lambda$} & \multirow{2}{*}{$0.14 q$} & 1.77 & $r \leqslant .10$ & $r \cdot$ & ذكر & \multirow{2}{*}{ بلآثار التربوية للتعليم عن } \\
\hline & & & $\vee . \mu \wedge$ & YV.IY & $\varepsilon 0$. & & \\
\hline \multirow{2}{*}{.1} & \multirow[t]{2}{*}{$V \leq \Lambda$} & \multirow{2}{*}{$\varepsilon .1 Y q$} & 9.7 & $r \wedge .9 r$ & $r \ldots$ & ذكر & \multirow{2}{*}{ الآثار التربوية للتعليم عن } \\
\hline & & & V.7 & 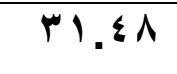 & $\leqslant 0$. & & \\
\hline \multirow[t]{2}{*}{.1} & \multirow[t]{2}{*}{$V \varepsilon \Lambda$} & \multirow[t]{2}{*}{ r.YVT } & $\vee . \mu \wedge$ & $r 1 . \cdot r$ & $r \ldots$ & & \multirow{2}{*}{ الآثار التربوية للتعليم عن } \\
\hline & & & 7.6 & YY. Y & $\varepsilon 0$. & أنثى & \\
\hline \multirow[t]{2}{*}{. .1} & \multirow[t]{2}{*}{$V \varepsilon \wedge$} & \multirow[t]{2}{*}{$r . r . r$} & 7.01 & IV.VY & $r \ldots$ & ذكر & \multirow{2}{*}{ الآثار التربوية للتعليم عن } \\
\hline & & & 0.19 & 19.18 & $\leqslant 0$. & أنثى & \\
\hline \multirow[t]{2}{*}{$\because \cdot 1$} & \multirow[t]{2}{*}{$V \varepsilon \Lambda$} & \multirow[t]{2}{*}{$\varepsilon}$. & $\varepsilon Y . O Y$ & $|\Psi| \cdot V$ & $r \ldots$ & ذكر & \multirow[t]{2}{*}{ الاستبانة ككل } \\
\hline & & & $r 0 . \Lambda V$ & $1 \leq Y . V 1$ & $\leqslant 0$. & أنظى & \\
\hline
\end{tabular}


الآثار التريوية للتعليم عن بعد لاى طلاب الجامعات أثناء جائحة كورونا (أ.د/فاطمة محمد عبد الوهاب الخليفة )

يتضح من جدول (V) ما يلي:

- ـ وجود فرق ذو دلالة إحصائية عند مستوى ( 0.01 a لمتغير الجنس في الاستبانة ككل وفي كل محور من محاورها الخمسة لصالح أفراد العينة من الإناث. وبالتالي يرفض الفرض الثاني من فروض الدراسة ويقبل الفرض البديل "توجد فروق دالة إحصائيا بين متوسطي درجات عينة الدر اسة عند مستوى دلالة 0.05 > في الاستبانة ككل وفي كل محور من محاور ها الخمسة تبعاً لمتغير الجنس وذللك لصالح أفر اد العينة من الإناث. عـ للإجابة عن السؤال الرابع من أسئلة الدراسة وهو " ما دلالة الفروق الإحصائية بين متوسط درجات طلاب الكليات عن الآثار التربوية للتعلم عن بعد والتي ترجع الى التخصص (التربوية ـ الطبية- الهندسية - العلوم الأساسية)؟ وللتحقق من صحة الفرض الثالث: لا توجد فروق دالة إحصائيا بين متوسطي درجات عينة الدراسة عند مستوى دلالة 0.05 ف في الاستبانة ككل وكذلك في كل بعد من أبعادها الخمسة وفقاً لمتغير القطاع التخصصي (القطاع التربوي - قطاع العلوم الأساسية - القطاع الطبي- قطاع العلوم الهندسية).

لاختبار صحة الفرض الثالث تم حساب اختبار تحليل التباين أحادي الاتجاه لحساب الفرق بين متوسطي درجات أفر اد العينة وفقاً لقطاع التعليم في الاستبانة ككل وفي كل محور من محاورها الخمسة، وظهرت النتائج كما هو موضح بالجدول الآتي:

جدول (^)

البيانات الوصفية لاستجابات أفراد عينة الدراسة في الاستبانة وفقاً لمتغير القطاع التخصصي

\begin{tabular}{|c|c|c|c|c|}
\hline الاتحراف المعياري & المتوسط الحسابي & العدد & القطاعات & المحاور \\
\hline $1 \cdot .9 V$ & $\varepsilon r . M$ & YYY & التربوية & \multirow{5}{*}{ 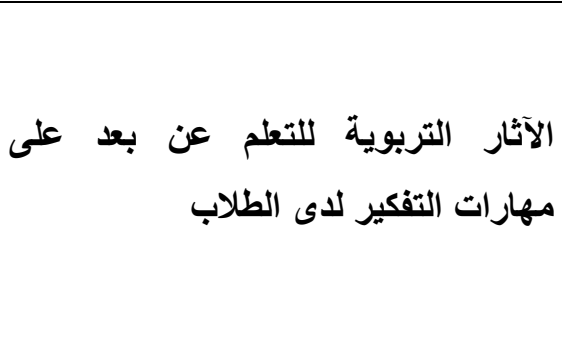 } \\
\hline 14.71 & $r \wedge . \wedge r$ & $19 V$ & العلوم الأساسية & \\
\hline 14.10 & rq.V. & $1 \leqslant 9$ & الطبية & \\
\hline 11.21 & $\& 1 . V$. & $1 \leqslant Y$ & الهندسية & \\
\hline IY.rV & 21.11 & Vo. & الإجمالي & \\
\hline V.Yq & rV.19 & YYY & التربوية & \multirow{4}{*}{ 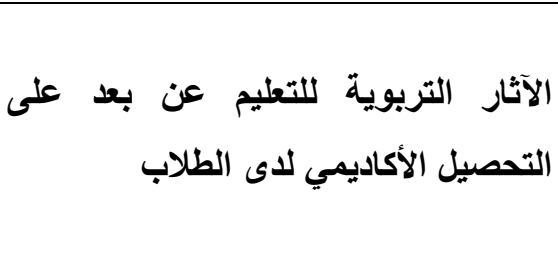 } \\
\hline A.VY & $Y \leqslant . \leqslant 7$ & $19 V$ & العلوم الأساسية & \\
\hline$\Lambda . \leqslant 1$ & Y०.Ar & $1 \leqslant 9$ & الطبية & \\
\hline V.VI & YO.VO & $1 \leqslant Y$ & الهندسية & \\
\hline
\end{tabular}


الآثار التريوية للتعليم عن بعد لاى طلاب الجامعات أثناء جائحة كورونا المجلة العربية للقياس والتقويم

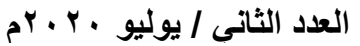

(أ.د/فاطمة محمد عبد الوهاب الخليفة )

\begin{tabular}{|c|c|c|c|c|}
\hline الانحراف المعياري & المتوسط الحسابي & العدد & القطاعات & المحاور \\
\hline $1 . \cdot \varepsilon$ & ro.qr & Vo. & الإجمالي & \\
\hline$V . \mu V$ & 19.79 & YYr & التربوية & \multirow{5}{*}{ 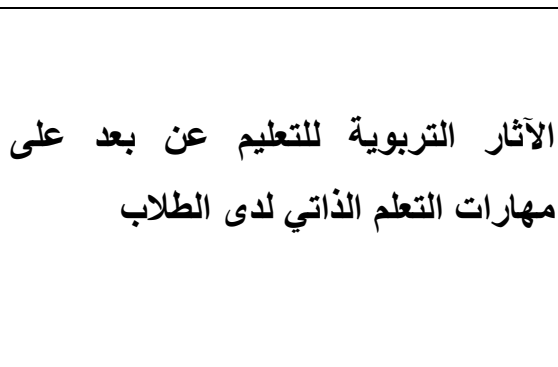 } \\
\hline 9.8 & $r q . r V$ & $19 V$ & العلوم الأساسية & \\
\hline $9.0 Y$ & 99.79 & $1 \leq 9$ & الطبية & \\
\hline$V . \varepsilon 0$ & $r \cdot .7 V$ & $1 \leqslant Y$ & الهندسية & \\
\hline A.Mo & $r \cdot . \varepsilon q$ & Vo. & الإجمالي & \\
\hline 7.11 & $r$ r... & rצr & التربوية & \multirow{5}{*}{ 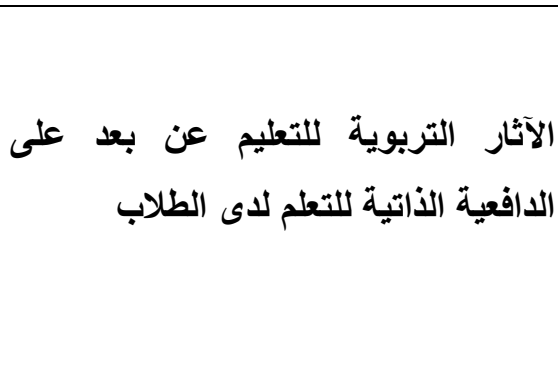 } \\
\hline $8.1 \mathrm{H}$ & $r \cdot . q$. & $19 V$ & العلوم الأساسية & \\
\hline I.AY & YI.YE & $1 \leqslant 9$ & الطبية & \\
\hline $7.0 \%$ & YY.EY & $1 \leqslant Y$ & الهنلسية & \\
\hline 7.77 & 11.99 & Vo. & الإجمالي & \\
\hline 0.21 & $19.0 Y$ & rצr & التربوية & \multirow{5}{*}{ 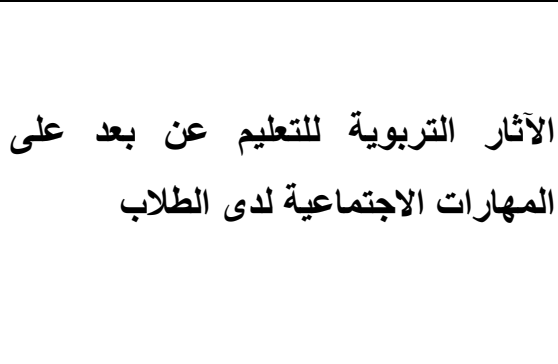 } \\
\hline $7 . Y \varepsilon$ & 18.90 & $19 V$ & العلوم الأسـاسية & \\
\hline $0.7 Y$ & $18.9 \leq$ & $1 \leq 9$ & الطبية & \\
\hline 0.81 & IN.TY & $1 \leqslant Y$ & الهندسية & \\
\hline 0.199 & $11.0 \mathrm{~V}$ & Vo. & الإجمالي & \\
\hline ro.7. & $\mid \leq \varepsilon . V 1$ & YYr & التربوية & \multirow{5}{*}{ الاستبانة ككل } \\
\hline$\varepsilon Y . M r$ & $|r| . \& \mid$ & $19 V$ & العلوم الأساسية & \\
\hline$\$ 1.17$ & $\mid r \varepsilon . \mu$ & $1 \leqslant 9$ & الطبية & \\
\hline P..09 & 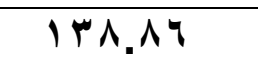 & $1 \leqslant Y$ & الهندسية & \\
\hline$r q .7$ & $1 \mu \Lambda_{.} \cdot q$ & Vo. & الإجمالي & \\
\hline
\end{tabular}

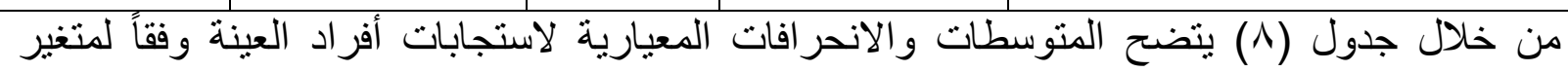
القطاع التخصصي في الاستبانة ككل وفي كل محور من محاور ها الخمسة. ولتحديد دلالة الفروق بين متوسطات استجابات عينة الدراسة وفقا لمتغير القطاع في الاستبانة ككل وفي كل محور من محاور ها تم حساب تحليل التباين أحادي الاتجاه، ويوضح جدول (9) نتائج اختبار تحليل التباين أحادي الاتجاه. 
الآثار التربوية للتعليم عن بعد لاى طلاب الجامعات أثناء جائحة كورونا

جدول (9)

نتائج اختبار (ANOVA) لالالة الفروق بين متوسطات استجابات عينة الدراسة وفقاً لمتغير القطاع في الاستبانة ككل وفي كل محور من محاورها

\begin{tabular}{|c|c|c|c|c|c|c|}
\hline الدلالة & قيمة ف & متوسط & الحرية & المربعات & البيان & | المحاور \\
\hline \multirow{3}{*}{$\because \cdot 1$} & \multirow{3}{*}{$0 . \wedge \wedge 1$} & $\overline{A \Lambda Y}$ & $r$ & 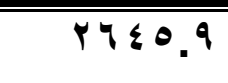 & بين المجموعات & \multirow{3}{*}{ لالدى الطار التربوية للتعلم عن مهارات التفكير } \\
\hline & & 10. & $V \leqslant 4$ & W $11 \wedge v \varepsilon . \varepsilon$ & داخل & \\
\hline & & & $V \leqslant 9$ & $11 \leqslant 0 Y \cdot .0$ & المجموع & \\
\hline \multirow{3}{*}{$\because+1$} & \multirow{3}{*}{ 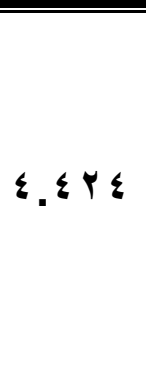 } & rAY.z & $\bar{T}$ & $\Lambda \leq V . r$ & بين المجموعات & \multirow{3}{*}{ الأكاديمي لآلى الطلار التربوية للتعليم عن } \\
\hline & & 7r.A & $V \leqslant 7$ & EVTrY.I & المجموعات & \\
\hline & & & $V \leqslant q$ & $\varepsilon \wedge \leqslant \vee \cdot . \varepsilon$ & المجموع & \\
\hline \multirow{3}{*}{$\because \cdot 1$} & \multirow{3}{*}{ r.VTr } & YOV.r & $\bar{r}$ & $\overline{V V Y}$ & بين المجموعات & \multirow{3}{*}{ الآلآثار التربوية للتعليم عن مهارات التعلم } \\
\hline & & $7 \wedge .9$ & $V \leq 7$ & $01 \leqslant r \leqslant . r$ & المجموعات & \\
\hline & & & $V \leqslant q$ & $0 Y 194 . r$ & المجموع & \\
\hline \multirow{3}{*}{$\because \cdot 1$} & \multirow{3}{*}{.791} & $r \cdot \varepsilon$ & $\bar{r}$ & 715 & بين المجموعات & \multirow{3}{*}{ 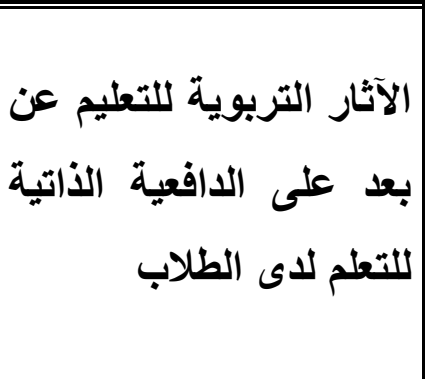 } \\
\hline & & $\varepsilon r . \wedge$ & $V \leqslant 7$ & ry & المجلموعات & \\
\hline & & & $V \leqslant 9$ & PrYq.q & المجموع & \\
\hline
\end{tabular}


الآثار التريوية للتعليم عن بعد لاى طلاب الجامعات أثناء جائحة كورونا المجلة العربية للقياس والتقويم

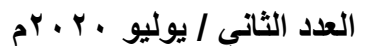

(أ.د/فاطمة محمد عبد الوهاب الخليفة )

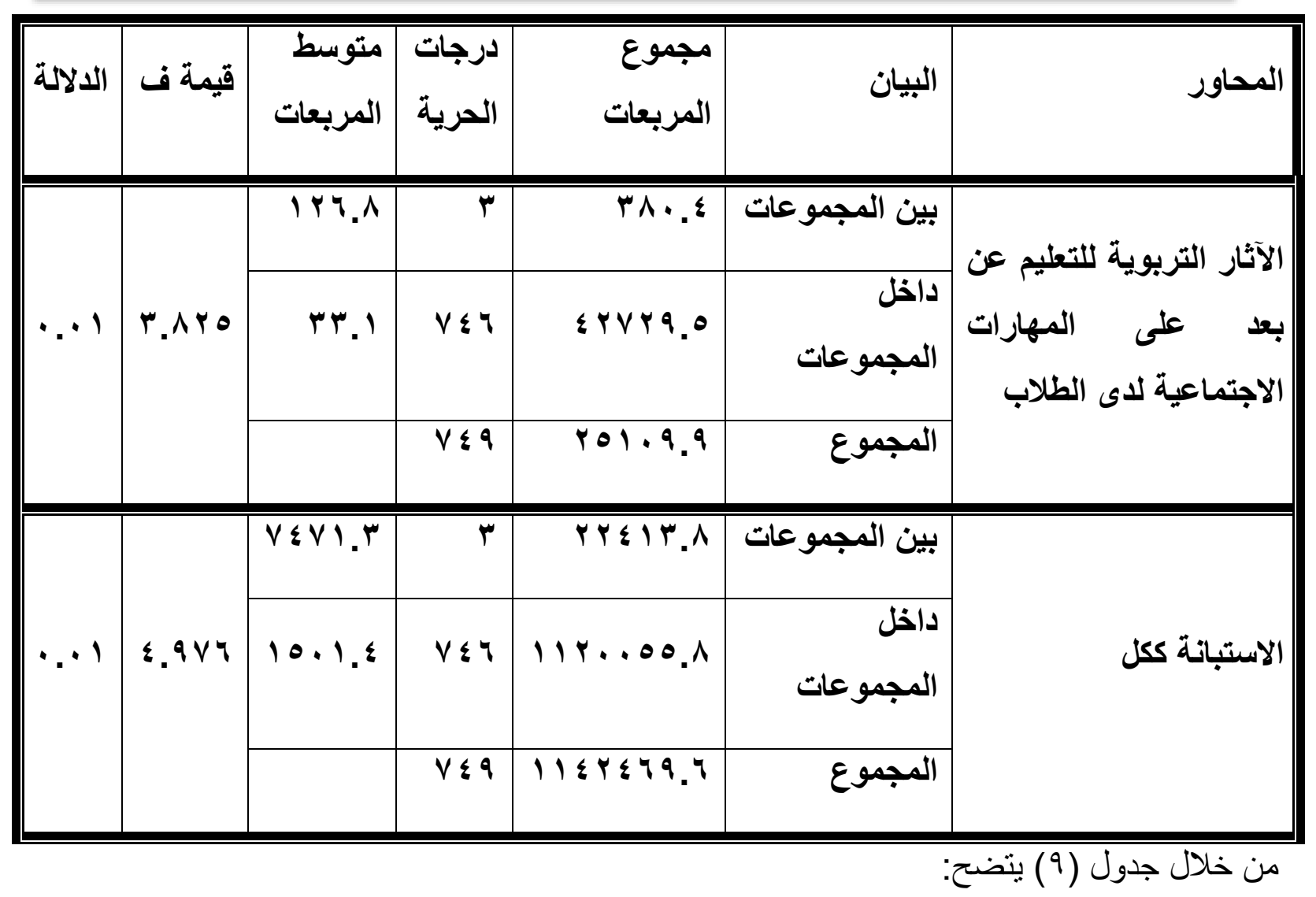

- قيمة (ف) دالة إحصائياً عند مستوى دلالة (1 .. · ) بالنسبة للاستبانة ككل وفي كل محور من المحاور الخمسة للاستبانة. مما يعني وجود فروق ذات دلالة إحصائية بين متوسطات درجات أفر اد العينة في الاستبانة ككل وفي كل محور من محاورها الخمسة وفقاً لمتغير القطاع.

وللتحقق من اتجاهات الفروق واجر اء مقارنات بعدية متعددة من أجل تحديد الفروق بين المتوسطات في الاستبانة ككل وكل محور من محاور ها الخمسة، تم استخدام اختبار شافيه، ونتائج الجدول الآتي يوضح ذلك. 
الآثار التريوية للتعليم عن بعد لاى طلاب الجامعات أثناء جائحة كورونا

(أ.د/فاطمة محمد عبد الوهاب الخليفة )

$$
\text { جدول (1·) }
$$

نتائج اختبار شافيه Scheffe، بين متوسطات درجات أفراد العينة في الاستبانة ومحاورها وفقاً لمتغير القطاع التخصصي

\begin{tabular}{|c|c|c|c|c|c|}
\hline الهزيسية & الطبية & العلوم . & المتوسط & القطاعات & \\
\hline 1.71 & *T. Y. & $* \varepsilon . \leqslant 9$ & $\varepsilon r . M$ & التربوية & \multirow{4}{*}{ الطلى الأثار التربوية للتعلم عن بعد } \\
\hline$Y . \wedge \wedge$ &.$\wedge \wedge \vee$ & & $r \wedge . \wedge r$ & الأسلوم & \\
\hline \multirow[t]{2}{*}{1.99} & & & rq.V. & الطبية & \\
\hline & & & $\& 1 . V$. & الهندسية & \\
\hline $1 . \varepsilon \varepsilon$ & 1.19 & *Y.VY & $r V .19$ & التربوية & \multirow{4}{*}{ الآثار التربوية للتعليم عن بعد التحيل الأكاديمي لاى } \\
\hline $1 . r q$ & $1 . \mu v$ & & $r \leq . \leq Y$ & الأساسية & \\
\hline \multirow[t]{2}{*}{$\because 99$} & & & $r \otimes . \wedge r$ & الطبية & \\
\hline & & & YO.VO & الهندسية & \\
\hline 1.9 & $Y . r$ & *Y.\&1 & 11.79 & التريوية & \multirow{4}{*}{ الطلاب مهار التخات التعلم الذاتي للتى عن بعد } \\
\hline $1 . \varepsilon$ &..$r q$ & & rq. rV & الأسلوم & \\
\hline \multirow[t]{2}{*}{1.1} & & & 79.79 & الطبية & \\
\hline & & & $r . .7 v$ & الزهـسية & \\
\hline. .01 & 1.17 & *Y.1. & rr... & التربوية & \multirow{2}{*}{ الآثار التربوية للتعليم عن بعد الدافعية الأتية للتعلم لاى } \\
\hline $1.0 Y$ & $\cdot . r \varepsilon$ & & $r \cdot . q$. & العلوم & \\
\hline
\end{tabular}


الآثار التريوية للتعليم عن بعد لاى طلاب الجامعات أثناء جائحة كورونا المجلة العربية للقياس والتقويم

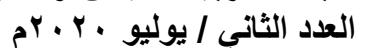
(أ.د/فاطمة محمد عبد الوهاب الخليفة )

\begin{tabular}{|c|c|c|c|c|c|}
\hline & & & & الأساسية & الطلاب \\
\hline \multirow[t]{2}{*}{1.11} & & & YI.Y & الطبية & \\
\hline & & & $Y Y . \& Y$ & الزهنسية & \\
\hline $1 . Y$. & $1.0 \mathrm{~V}$ & $* 1.01$ & $19.0 Y$ & التربوية & \multirow{4}{*}{ الطلاب الآثار التربوية للتعليم عن بعد } \\
\hline.$\mu V$ & $\because r$ & & $1 V .90$ & الأسلوم & \\
\hline \multirow[t]{2}{*}{$\cdot . \mu \Lambda$} & & & $1 V .9 \varepsilon$ & الطبية & \\
\hline & & & IN.MY & الزهنسية & \\
\hline $0 . \wedge 0$ & $1 \cdot . \mu r$ & *Ir.r. & $\begin{array}{r}1 \leq \varepsilon .7 \\
1\end{array}$ & التربوية & \multirow{4}{*}{ الإستبانة ككل } \\
\hline$V . \leqslant 0$ & Y.q^ & & & & \\
\hline \multirow[t]{2}{*}{$\varepsilon . \leqslant 1$} & & & $\begin{array}{r}1 T \leqslant . r \\
\Lambda\end{array}$ & الطبية & \\
\hline & & & $\begin{array}{r}1 \% \wedge . \wedge \\
4\end{array}$ & الهزسية & \\
\hline & & & $((\cdot .0)$ & كسائيا عند & * تدل على وجود فروق دالة إح \\
\hline
\end{tabular}

- وجود فروق ذات دلالة احصائية عند مستوى دلالة (0 . . ) بين متوسطي درجات أفر اد العينة في القطاعين التربوي والعلوم الأساسية في الاستبانة ككل وفي كل محور من محاور ها الخمسة لصالح منوسط درجات أفر اد العينة في القطاع التربوي. - وجود فروق ذات دلالة احصائية عند مستوى دلالة (0. . • ) بين متوسطي درجات أفر اد العينة في القطاعين التربوي والطبي في محور الأثار التربوية للتعليم عن بعد على 
الآثار التريوية للتعليم عن بعد لاى طلاب الجامعات أثناء جائحة كورونا

(أ.د/فاطمة محمد عبد الوهاب الخليفة )

مهارات التفكير لدى الطلاب فقط لصالح منوسط درجات أفراد العينة في القطاع التربوي.

- عدم وجود فروق دالة احصائيا بين متوسط درجات أفراد العينة في قطاع العلوم

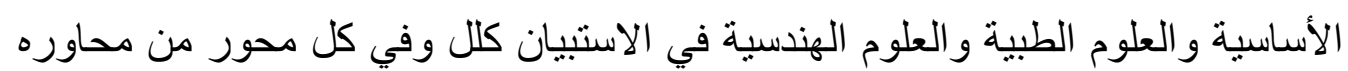

الخمسة.

- عدم وجود فروق بين باقي القطاعات في الاستبانة ككل وفي جميع محاور ها.

وبذلك يتحقق الفرض الثالث من فروض الدراسة وهو" لا توجد فروق دالة إحصائيا بين متوسطي درجات عينة الدراسة عند مستوى دلالة 0.05 a في الاستبانة ككل وكذلك في كل بعد من أبعادها الخمسة وفقاً لمتغير القطاع التخصصي (القطاع التربوي ـ قطاع العلوم الأساسية - القطاع الطبي-

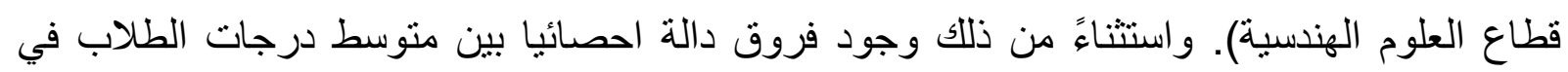

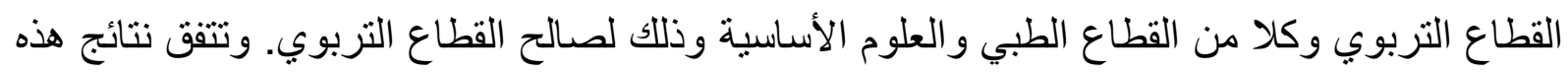

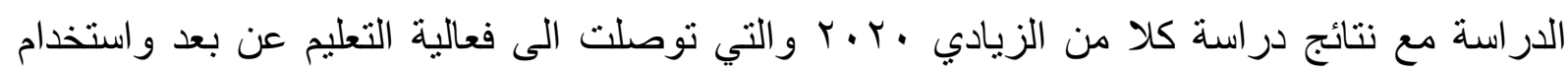

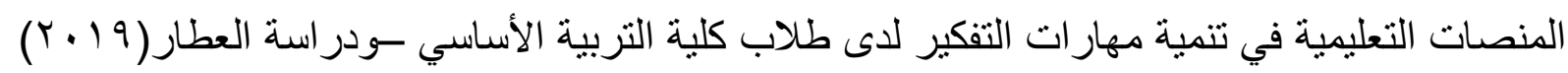

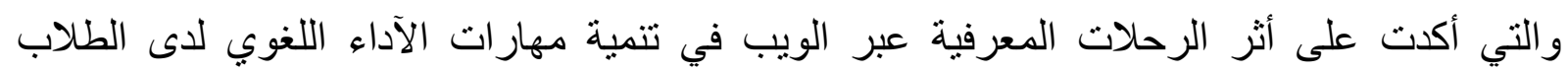

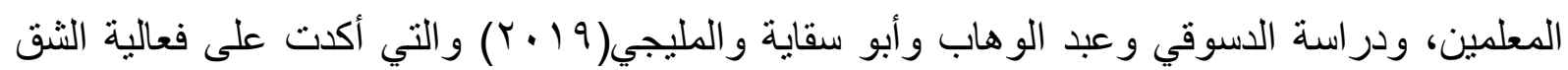

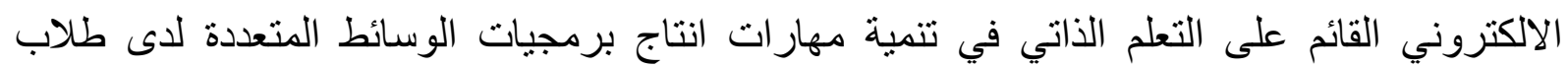

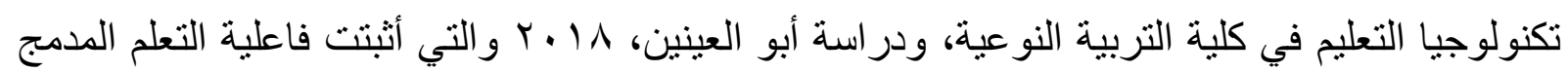

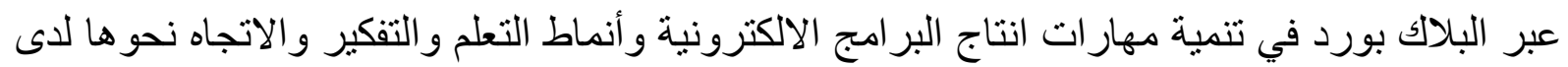

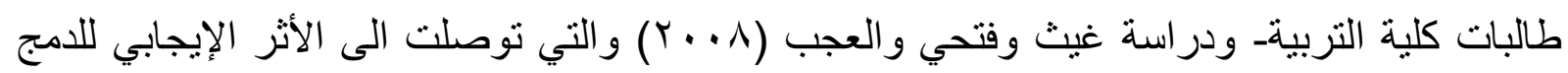

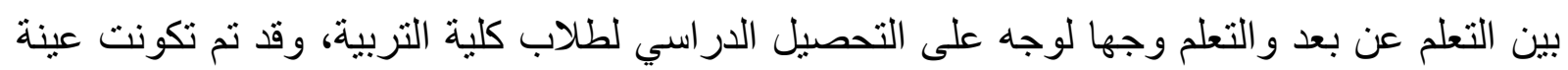
الدراسة من V9 طالبا وطالبة من طلاب كلية التربية، وقد أظهرت الدراسة الأثر الإيجابي لنظام التعلم المدمج على التحصيل الدراسي وإظهار رضا الطلاب عن مقرر استراتيجيات التدريس.

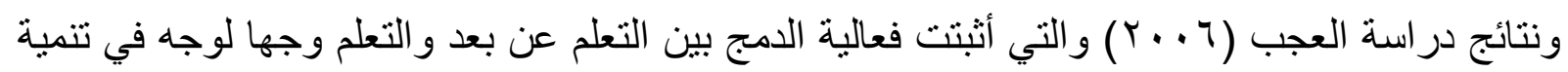
التحصيل و المهار ات العملية لدى طلاب المرحلة قبل الطبية. هـ للإجابة عن السؤال الخامس من أسئلة الدراسة والذي ينص على "ما دلالة الفروق الإحصائية بين منوسط درجات طلاب الجامعات عن الآثار التربوية والتي ترجع الى الفرقة الدراسية (الأولى-

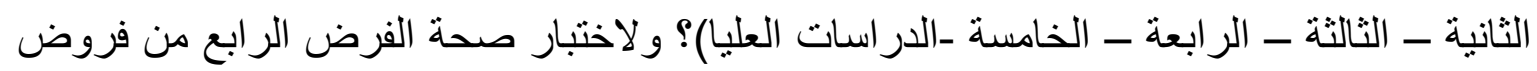


الآثار التريوية للتعليم عن بعد لاى طلاب الجامعات أثناء جائحة كورونا المجلة العربية للقياس والتقويم

(أ.د/فاطمة محمد عبد الوهاب الخليفة )

الدراسة والذي ينص على "لا توجد فروق دالة إحصائيا بين متوسطي درجات عينة الدراسة عند مستوى دلالة a 0.05 في الاستبانة ككل وكذلك في كل محور من محاور ها الخمسة وفقاً لمتغير الفرقة الدر اسية (الأولى ـ الثانية ـ الثالثة ـ الر ابعة ـ الخامسة ـ الدر اسات العليا)".

لاختبار صحة الفرض الرابع تم حساب اختبار تحليل التباين أحادي الاتجاه لحساب الفرق بين متوسطي درجات أفراد العينة وفقاً للفرقة الدراسية في الاستبانة ككل وفي كل محور من محاورها الخمسة، لانحان

وظهرت النتائج كما هو موضح في جدول (11):

جدول (1 1) البيانات الوصفية لاستجابات أفراد عينة الدراسة في الاستبانة وفقاً لمتغير الوظيفة الحالية

\begin{tabular}{|c|c|c|c|c|}
\hline الانحراف المعياري & المتوسط الحسابي & العدد & الفرقة & المحاور \\
\hline $1 \cdot .1 \varepsilon$ & $\varepsilon Y . O r$ & $10 Y$ & الأولى & \multirow{7}{*}{ لالأثار التربوية للتعلم عن الطلاب مهار ات التفكير } \\
\hline 11.70 & $\varepsilon r . V Y$ & $1 \% 7$ & الثانية & \\
\hline IY. E E & $\varepsilon r . \wedge q$ & 191 & الثالثة & \\
\hline $1 \% .11$ & $r 0.9 r$ & Yr. & الر ابعة & \\
\hline 1.71 & rq.rY & r & الخامسة & \\
\hline$V . Y_{1}$ & $\leq 9.1$. & $\varepsilon$. & 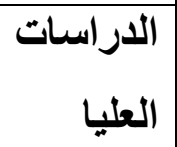 & \\
\hline IY.YV & $\$ 1.11$ & Vo. & الإجمالي & \\
\hline $7.9 \mathrm{~V}$ & Y०.Ao & $10 Y$ & الأولى & \multirow{5}{*}{ الآنثار التربوية للتعليم } \\
\hline$v .19$ & $r V . \wedge r$ & I & الثانية & \\
\hline$V . \varepsilon q$ & $r v . v$. & 171 & الثالثة & \\
\hline $1.9 Y$ & $Y Y . \wedge \Lambda$ & $r r$. & الر ابعة & \\
\hline $7 . r$ & rr.1. & l & الخامسة & \\
\hline
\end{tabular}


الآثار التريوية للتعليم عن بعد لاى طلاب الجامعات أثناء جائحة كورونا

(أ.د/فاطمة محمد عبد الوهاب الخليفة )

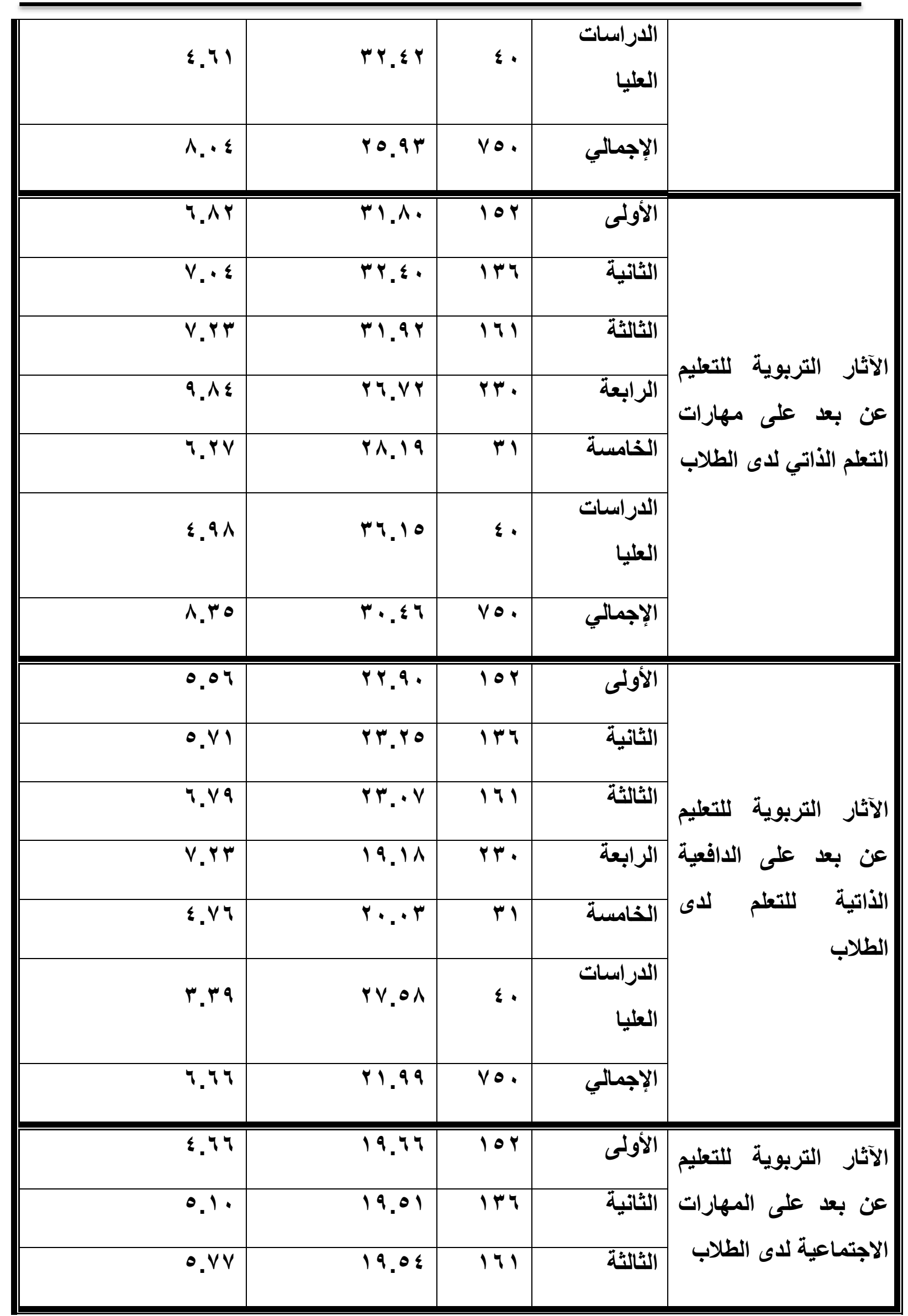


الآثار التريوية للتعليم عن بعد لاى طلاب الجامعات أثناء جائحة كورونا

(أ.د/فاطمة محمد عبد الوهاب الخليفة )

\begin{tabular}{|c|c|c|c|c|}
\hline 7.11 & 17.18 & $r r$. & الرابعة & \\
\hline 0.19 & 17.11 & $r$ & الخامسة & \\
\hline$\varepsilon . \varepsilon Y$ & $r r . .$. & $\varepsilon$. & الار اسات & \\
\hline 0.19 & $11.0 \mathrm{~V}$ & Vo. & الإجمالي & \\
\hline rI.Y & $1 \varepsilon Y . V \varepsilon$ & $10 \%$ & الأولى & \multirow{7}{*}{ الاستبانة ككل } \\
\hline r.VH & $1 \leq 7.81$ & 114 & الثانية & \\
\hline$r V_{.0} 0$ & $1 \leq 7.1 Y$ & 171 & الثالثة & \\
\hline$\varepsilon \varepsilon \ldots$ & $I Y \cdot . A V$ & rr. & الر ابعة & \\
\hline Yq.Yr & IYY.VV & rI & الخامسة & \\
\hline$Y 1.71$ & $171 . Y 0$ & $\varepsilon$. & الألعات اسبات & \\
\hline 19.9 & $1 \% \Lambda_{.} \cdot 7$ & Vo. & الإجمالي & \\
\hline
\end{tabular}

يوضح جدول (1) المتوسطات والانحر افات المعيارية لاستجابات أفراد العينة وفقاً لمتغير الفرقة الدراسية في الاستبانة ككل وفي كل محور من محاور ها الخمسة. ولتحديد دلالة الفروق بين متوسطات استجابات عينة الدراسة وفقاً لمتغير الفرقة الدراسية في الاستباتة ككل وفي كل محور من محاورها الخمسة تم حساب اختبار تحليل التباين أحادي الاتجاه (ANOVA) ويوضح جدول (r I) هذه النتائج: 
الآثار التريوية للتعليم عن بعد لاى طلاب الجامعات أثناء جائحة كورونا

(أ.د/فاطمة محمد عبد الوهاب الخليفة )

\section{جدول (r)}

نتائج اختبار (ANOVA) لالالة الفروق بين متوسطات استجابات عينة الدراسة وفقاً لمتغير الفرقة الار اسية في الاستبانة ككل وفي كل محور من محاورها الخمسة

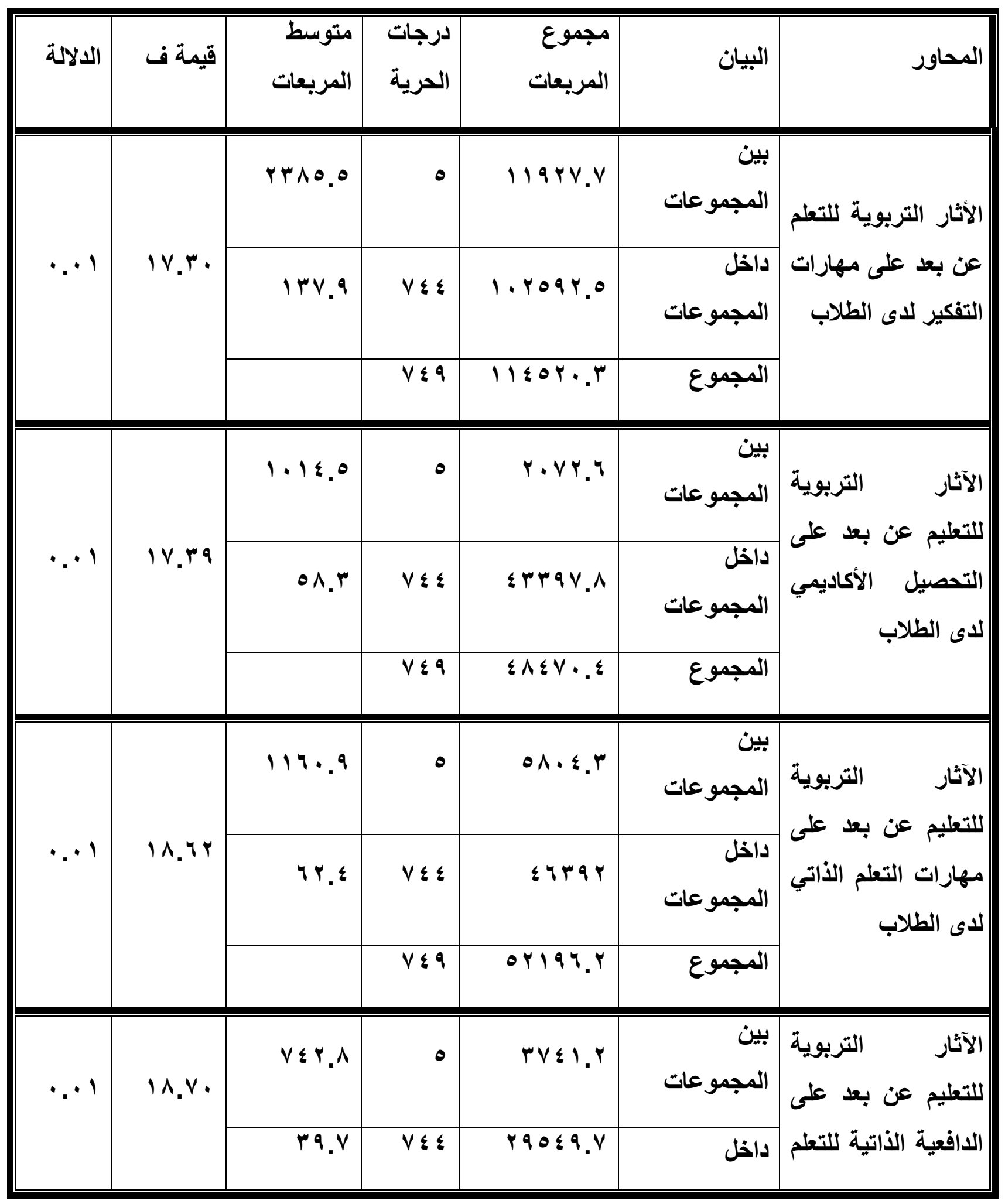


الآثار التريوية للتعليم عن بعد لاى طلاب الجامعات أثناء جائحة كورونا المجلة العربية للقياس والتقويم

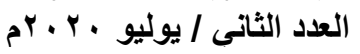

(أ.د/فاطمة محمد عبد الوهاب الخليفة )

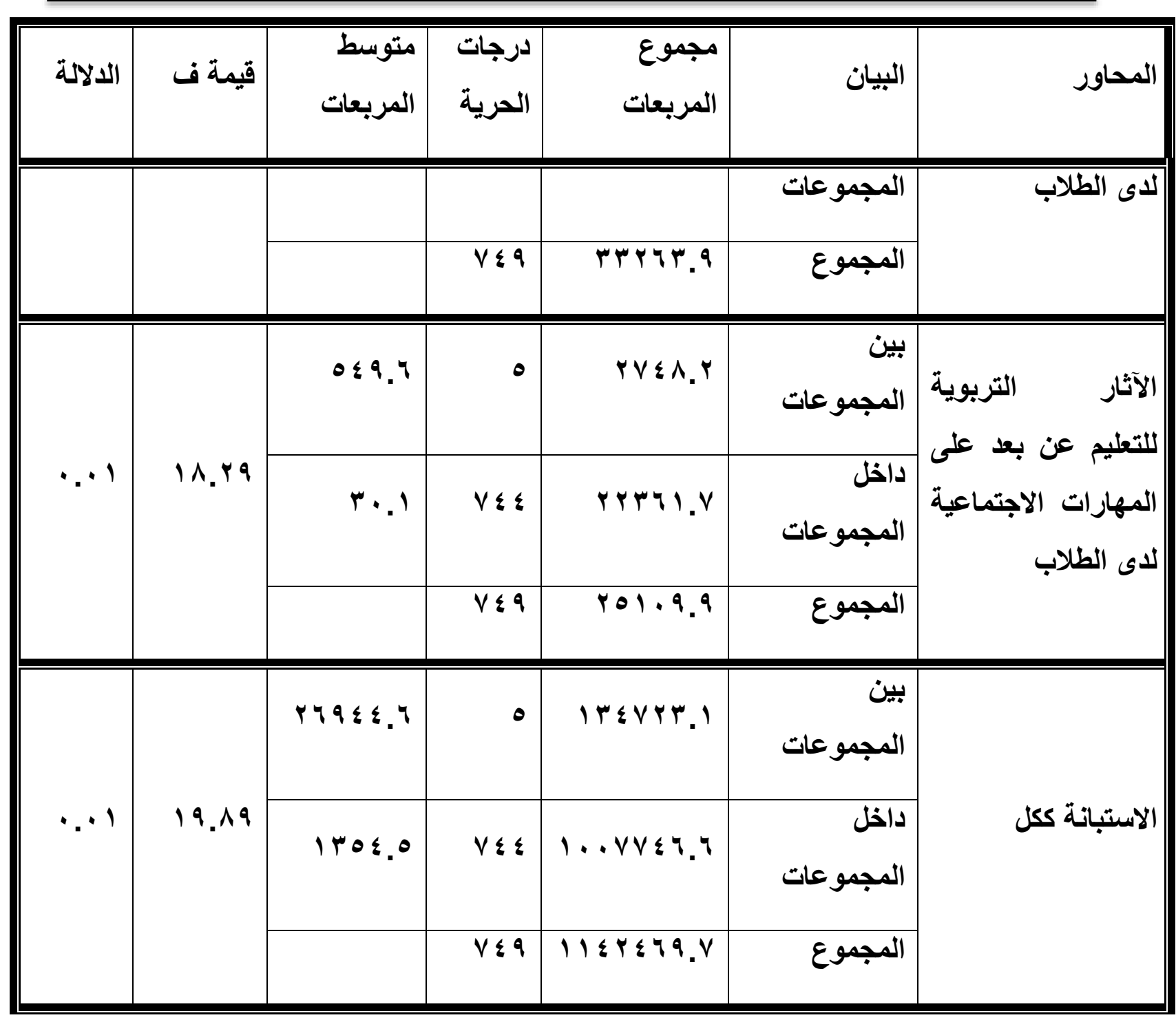

\section{يتضح من جدول (Y I ) ما يأتي:}

- قيمة (ف) دالة إحصائياً عند مستوى دلالة (1 . • ) بالنسبة للاستبانة ككل وفي كل محور من المحاور الخمسة للاستبانة. مما يعني وجود فروق ذات دلالة إحصائية بين متوسطات درجات أفر اد العينة في الاستبانة ككل وفي كل محور من محاور ها الخمسة وفقاً لمتغير الفرقة الدر اسية.

وللتحقق من اتجاهات الفروق واجر اء مقارنات بعدية متعددة من أجل تحديد الفروق بين المتوسطات في الاستبانة ككل وكل محور من محاور ها الخمسة، تم استخدام اختبار شافيه، ويوضح جدول (r I) هذه 
الآثار التريوية للتعليم عن بعد لاى طلاب الجامعات أثناء جائحة كورونا المجلة العربية للقياس والتقويم

(أ.د/فاطمة محمد عبد الوهاب الخليفة )

\section{جدول (r I )}

نتائج اختبار شافيه Scheffe، بين متوسطات درجات أفراد العينة في الاستبانة ومحاورها وفقاً لمتغير الفرقة الدراسية

\begin{tabular}{|c|c|c|c|c|c|c|c|}
\hline دراسات عليا & الخامسة & الرابعة & الثالثة & الثاتية & المتوسط & الفرقة & محاور \\
\hline .9 & $7 . Y 1$ & *4.71 & 1.54 & 1.19 & $\varepsilon r . O r$ & الأولى & \multirow{6}{*}{ 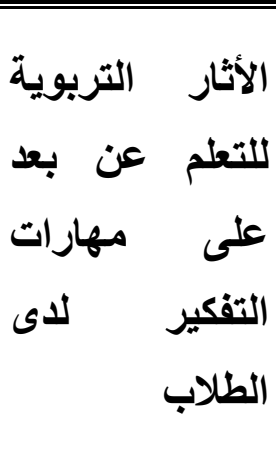 } \\
\hline $0 . \mu \wedge$ & $V . \varepsilon$. & $* V . \Lambda$. &. $.1 \mathrm{~V}$ & & $\varepsilon r . V Y$ & الثانية & \\
\hline $0 . Y_{1}$ & $V .0 V$ & $* V .9 V$ & & & $\varepsilon r . \wedge q$ & الثالثة & \\
\hline$* 1 T .1 \mathrm{~V}$ & $\because \varepsilon$ & & & & $r 0.9 r$ & الرابعة & \\
\hline \multirow[t]{2}{*}{ *I Y.VA } & & & & & M. & الخامسة & \\
\hline & & & & & $\leq 9.1$. & دراسات عليا & \\
\hline$* 4.01$ & r.Vo & *Y.qV & $1 . \wedge \varepsilon$ & 1.91 & Y०.^० & الأولى & \multirow{6}{*}{ لآلآثار التربوية } \\
\hline$* \varepsilon .09$ & $\varepsilon . V \mu$ & $* \leqslant .90$ & $.1 \leq$ & & YV.AT & الثانية & \\
\hline$* \varepsilon . V Y$ & $\varepsilon .7$. & $* \varepsilon . \wedge Y$ & & & YV.V. & الثالثة & \\
\hline$* 9.00$ & $\because Y Y$ & & & & 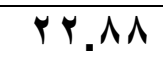 & الرابعة & \\
\hline \multirow[t]{2}{*}{$* q . r r$} & & & & & rr. & الخامسة & \\
\hline & & & & & $r Y . \& Y$ & دراسات عليا & \\
\hline$\varepsilon . \mu 0$ & T.7. & $* 0.11$ &. $.1 Y$ &. .71 & M. & الأولى & \multirow{6}{*}{ 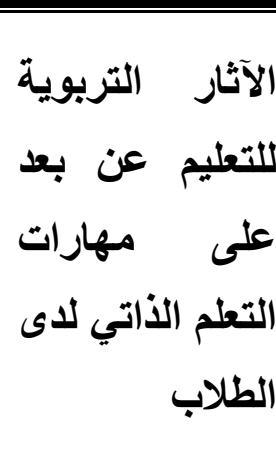 } \\
\hline r.Vo & $\{. Y$ & $* 0.79$ & $\cdot . \leqslant 9$ & & Mr.\&. & الثانية & \\
\hline$\varepsilon . Y r$ & $r . V r$ & $* 0 . Y$. & & & $r 1.9 r$ & الثالثة & \\
\hline$* q . \leqslant \mu$ & $1 . \leqslant 1$ & & & & YY.VY & الر ابعة & \\
\hline \multirow[t]{2}{*}{$* \vee . \vee 7$} & & & & & r^.19 & الخامسة & \\
\hline & & & & & $r .10$ & دراسات عليا & \\
\hline$* \varepsilon .7 V$ & r.AV & $* Y . V Y$ &. $.1 \mathrm{~V}$ & 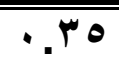 & rr.q. & الأولى & \multirow{6}{*}{ 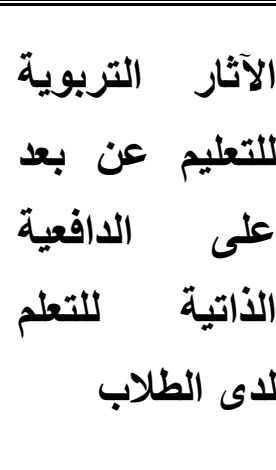 } \\
\hline$* \varepsilon . \mu \mu$ & Y.YY & $* \varepsilon . \cdot V$ &. .11 & & Yr.Yo & الثاتية & \\
\hline$* \varepsilon, 01$ & r. & $* \Psi . \wedge q$ & & & $r r . \cdot V$ & الثالثة & \\
\hline$* \Lambda . \varepsilon$. &.$\wedge 0$ & & & & 19.11 & الرابعة & \\
\hline \multirow[t]{2}{*}{$* V .0\}$} & & & & & $r \cdot . \cdot r$ & الخامسة & \\
\hline & & & & & $Y V .01$ & دراسات عليا & \\
\hline
\end{tabular}


الآثار التريوية للتعليم عن بعد لدى طلاب الجامعات أثناء جائحة كورونا المجلة العربية للقياس والتقويم

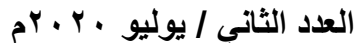

(أ.د/فاطمة محمد عبد الوهاب الخليفة )

\begin{tabular}{|c|c|c|c|c|c|c|c|}
\hline$* \mu . \mu r$ & r.or & $*$ *. 0 . &. $.1 r$ &. .17 & 19.77 & الأولى & \multirow{6}{*}{ 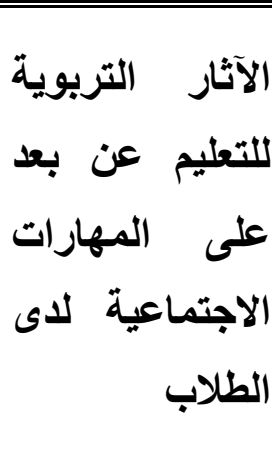 } \\
\hline$* 4 . \leqslant 9$ & r.MA & *Y.r & $\because r$ & & 19.01 & الثاتية & \\
\hline *r. & r. $\varepsilon 1$ & $* \mu . \mu V$ & & & $19.0 \varepsilon$ & الثالثة & \\
\hline$* ฯ . \wedge \mu$ & $\because \varepsilon$ & & & & 17.18 & الرابعة & \\
\hline \multirow[t]{2}{*}{$* \eta . \wedge V$} & & & & & $17.1 \%$ & الخامسة & \\
\hline & & & & & rr... & دراسات عليا & \\
\hline$* Y 0.01$ & $19.9 V$ & $\begin{array}{r}Y 1 . \Lambda V \\
*\end{array}$ & r. & $r .9 V$ & $\begin{array}{r}\& Y . V \\
\varepsilon\end{array}$ & الأولى & \multirow{6}{*}{ الإستبانة ككل } \\
\hline Y $1.0 \leq$ & YY.qE & $\begin{array}{r}r 0 . \wedge \varepsilon \\
*\end{array}$ &. .7 & & $\begin{array}{r}1 \leq 7.8 \\
1\end{array}$ & الثانية & \\
\hline *Yr. Ir & Yr.ME & $\begin{array}{r}r 0 . r 0 \\
*\end{array}$ & & & $\begin{array}{r}1 \leq 7.1 \\
r\end{array}$ & الثالثة & \\
\hline$* \varepsilon V, \mu \wedge$ & 9.91 & & & & $\begin{array}{r}I Y \cdot . \Lambda \\
V\end{array}$ & الر ابعة & \\
\hline \multirow[t]{2}{*}{$* \leq \varepsilon . \leqslant \wedge$} & & & & & $\begin{array}{r}\text { IYT.V } \\
V\end{array}$ & الخامسة & \\
\hline & & & & & $\begin{array}{r}171 . r \\
0\end{array}$ & دراسـات عليا & \\
\hline
\end{tabular}

$$
\begin{aligned}
& \text { * تدل على وجود فروق دالة إحصائيا عند مستوى (0. . ()) }
\end{aligned}
$$

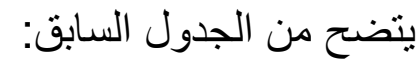

- بالنسبة لمحور الأثار التربوية للتعلم عن بعد على مهارات التفكير لاى الطلاب: تبين

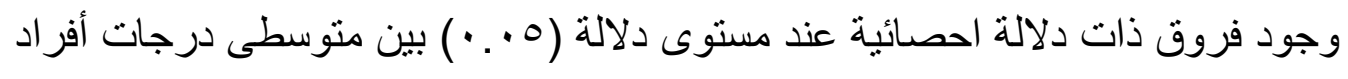

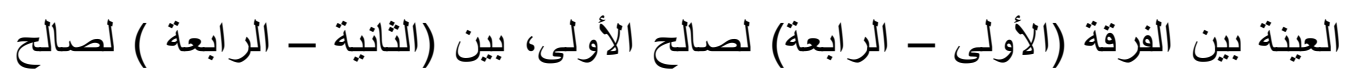

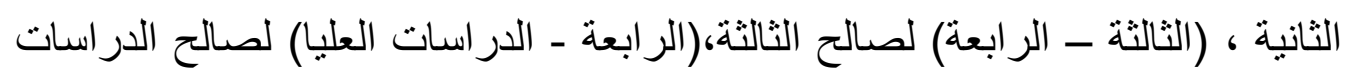

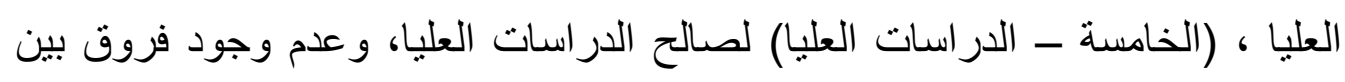
باقى الفرق وبعضهم البعض. - - بالنسبة لمحور الأثار التربوية للتعلم عن بعد على التحصيل الأكاديمي لدى الطلاب:

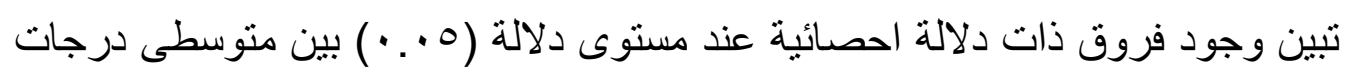


الآثار التريوية للتعليم عن بعد لاى طلاب الجامعات أثناء جائحة كورونا (أ.د/فاطمة محمد عبد الوهاب الخليفة )

أفراد العينة بين الفرقة (الأولى - الرابعة) لصالح الأولى، بين (الثانية - الرابعة )

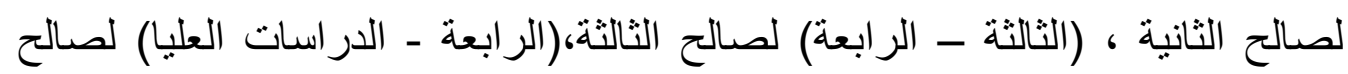
الدر اسات العليا ، (الر ابعة ـ الدر اسات العليا) لصالح الدر اسات العليا، وبين ( الأولى ـ

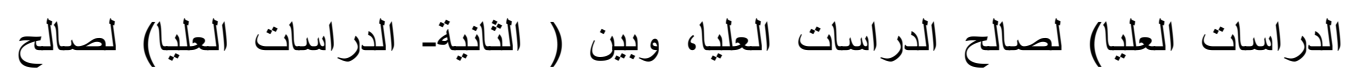
الدر اسات العليا، وبين (الخامسة ـ الدر اسات العليا) لصالح الدر اسات العليا وعدم وجود فروق بين باقي الفرق وبعضهم البعض. - - بالنسبة لمحور الأثنار التربوية للتعلم عن بعد على مهارات التعلم الذاتي لدى الطلاب: تبين وجود فروق ذات دلالة احصائية عند مستوى دلالة (0 . . ) بين متوسطى درجات بونات أفراد العينة بين الفرقة (الأولى - الرابعة) لصالح الأولى، بين (الثانية - الرابعة )

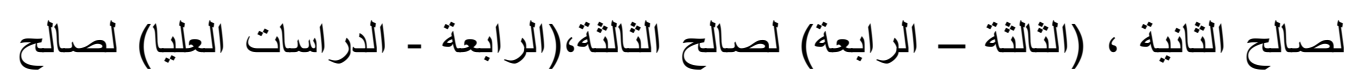
الدراسات العليا ، (الخامسة - الدراسات العليا) لصالح الدراسات العليا، وعدم وجود فروق بين باقى الفرق وبعضهم البعض.

- بالنسبة لمحور الأثنار التربوية للتعلم عن بعد على الدافعية الذاتية لدى الطلاب: تبين وجود فروق ذات دلالة احصائية عند مستوى دلالة (0. . • ) بين متوسطى درجات أفر اد

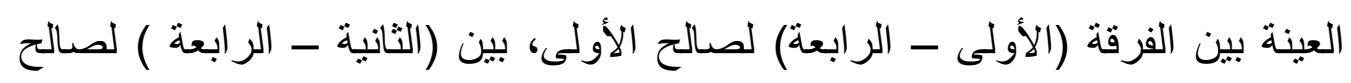

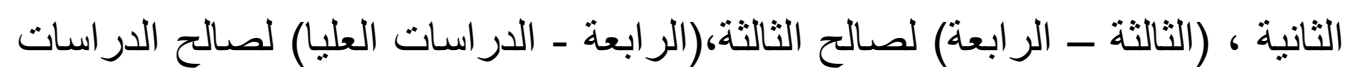

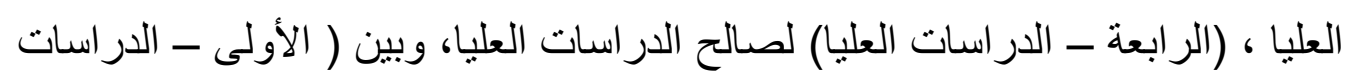
العليا) لصالح الدر اسات العليا، وبين ( الثانية- الدر اسات العليا) لصالح الدراسات العليا، وبين (الخامسة ـ الدر اسات العليا) لصالح الدراسات العليا و عدم وجود فروق بين باقي الفرق وبعضهم البعض. - بالنسبة لمحور الأثنار التربوية للتعلم عن بعد على المهارات الاجتماعية لدى الطلاب: تبين وجود فروق ذات دلالة احصائية عند مستوى دلالة (0 . . ) بين متوسطى درجات أفراد العينة بين الفرقة (الأولى - الرابعة) لصالح الأولى، بين (الثانية - الرابعة )

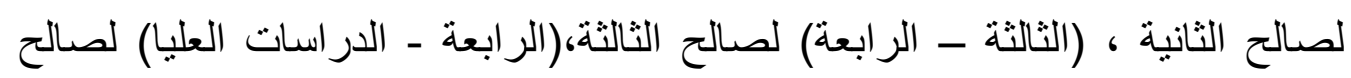
الدر اسات العليا ، (الر ابعة ـ الدر اسات العليا) لصالح الدر اسات العليا، وبين ( الأولى ـ

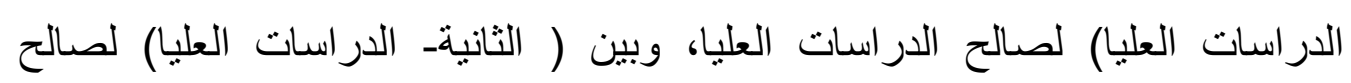
الدر اسات العليا، وبين (الخامسة ـ الدر اسات العليا) لصالح الدر اسات العليا وعدم وجود ولين فروق بين باقي الفرق وبعضهم البعض. 
الآثار التريوية للتعليم عن بعد لاى طلاب الجامعات أثناء جائحة كورونا

(أ.د/فاطمة محمد عبد الوهاب الخليفة )

- - بالنسبة لنتائج الاستبيان ككل والتي توضح الآثار التربوية للتعلم عن بعد على الطلاب في محاوره الخمس: تبين وجود فروق ذات دلالة احصائية عند مستوى دلالة (0.. · ) بين متوسطي درجات أفراد العينة بين الفرقة (الأولى ــ الرابعة) لصالح الأولى، بين

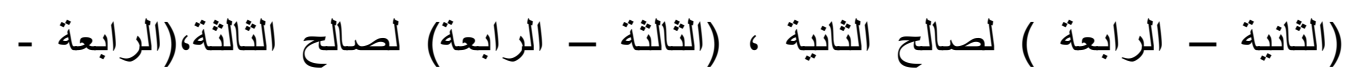

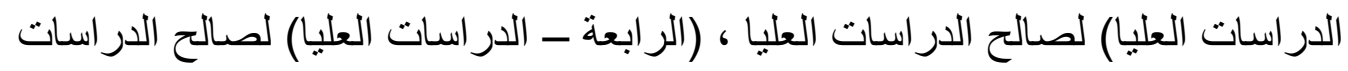
العليا، وبين ( الأولى ـ الدراسات العليا) لصالح الدراسات العليا، وبين ( الثانيةالدراسات العليا) لصالح الدراسات العليا، وبين (الخامسة ـ الدراسات العليا) لصالح الدر اسات العليا و عدم وجود فروق بين باقي الفرق وبعضهم البعض.

ويمكن تفسير هذه النتائج في ضوء خصائص طلاب مرحلة الدراسات العليا خاصة تمكنهم من مهار ات البحث العلمي، والتعلم الذاتي، وتمتعهم بالمهار ات اللازمة للتعامل و الاستفادة وتوظيف مصادر التعلم الالكترونية والتعلم عن بعد، وقدرتهم على الاستفادة من المصادر المتاحة لديهم، و أيضا در استهم لمقررات في مرحلة الدراسات العليا مكنتهم من مهارات البحث والاكتساب الفردي للمعرفة والاطلاع الدائم على مصادر ها، علاوة على قدرتهم على تحصيل المعلومات وجدولتها والاستفادة منها مستفيدين في ذلك من الدافعية الذاتية التي بتمتعون بها. التوصيات: في ضوء إجراءات الاراسة ونتائجها توصي بالآتي: اـ اجراء مزيد من الدراسات لتحديد الآثار التربوية للتعلم عن بعد على مجالات ومحاور أخرى غير التي تم در استنها. ץ- در اسة اتجاهات الطلاب نحو التعلم عن بعد خاصة ما تم استخدامه أثناء جائحة كورونا. r- تضمين مقررات للتعلم عن بعد والتعلم المدمج في التعليم الجامعي تركز وتوضح دور الطالب الجامعي في نجاح منظومة التعلم المدمج والتعلم عن بعد وتوظيف منصات التعلم الالكترونية في العملية التعليمية واجر اء الاختبار ات الالكترونية.

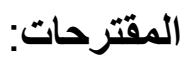

در اسة مقارنة للآثار التربوية لكل من التعلم عن بعد والتعلم المدمج على الطلاب في المرحلة الجامعية. در اسة الآثار الاجتماعية للتعلم عن بعد على طلاب المرحلة الجامعية. فعالية استخدام منصات التعلم الالكترونية في تتمية اتجاهات الطلاب ودافعيتهم نحو التعلم عن 


\section{المراجع}

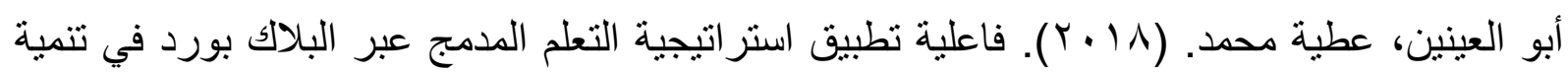
مهار ات انتاج البرامج الالكترونية وأنماط التعلم والتفكير والاتجاه نحوها لدى طالبات كلية

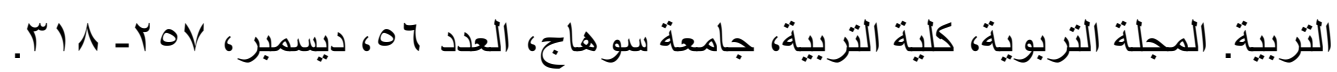

أبو عقل، وفاء. (r ( • (Y). أثر التعلم الالكتروني في تدريس العلوم على التحصيل الدراسي لدى دارسي جامعة القدس المفتوحة. المجلة الفلسطينية للتعليم المفتوح، المجلد الثالث، العدد السادس،

$$
.1 \% \mu-110
$$

اتحاد الأكاديميين والعلماء العرب. (·.Y.Y). مؤتمر عبر الانترنت، جائحة كورونا بين التحديات

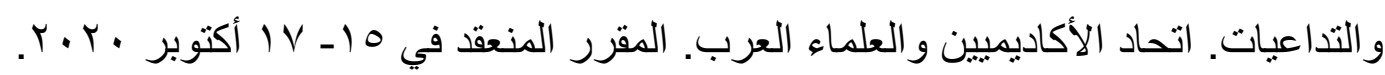

إسكندر، عايدة سيدهم و الوكيل، سيد احمد وسعيد، ماربيل ميلاد. (9 ( • ( ). أثر استخدام نمطين للتعليم المدمج ( المرن ـالفصول المقولبة) في تنمية بعض مهار ات برنامج الجداول الحسابية لدى

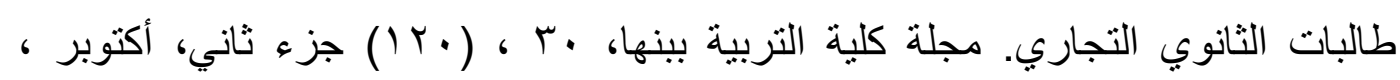

$$
\text { rrq }-r \cdot r
$$

أكاديمية رواد التميز للتعليم و التدريب و لاستشار ات و التنمية البشرية (PEATCHD)( • • (Y). التعلم الرقمي في الوطن العربي ( و اقعه، تحدياته، آفاقه المستقبلية) فيما بعد كورونا. المؤتمر الدولي الخامس لتطوير التعليم العربي، القاعات الصوتية للمنظمة وبرنامج الزووم، من

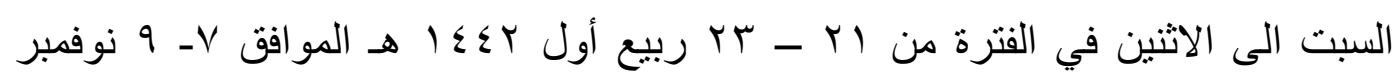

$$
. r \cdot r \cdot
$$

بباوي، در اد حكيم وتوفيق، رؤوف عزمي.(T ( ا Y). تصور مقترح للتقويم التكنولوجي لتحقيق التعلم الالكتروني النشط، المركز القومي للبحوث التربوية والتنمية، العدد ع.

بو كرديم، فدوى. (0 1 • ). استر اتيجيات التعلم عن بعد. مجلة العلوم الإنسانية، العدد ع ؛، ديسمبر، ror - r $\leqslant$ r

الجبر، حامد سعيد. (10 ب (Y). و اقع استخدام طلاب كلية التربية الأساسية في الكويت لأدوات التعلم

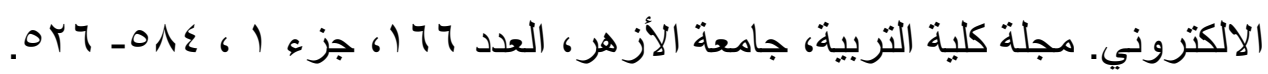


الآثار التريوية للتعليم عن بعد لاى طلاب الجامعات أثناء جائحة كورونا (أ.د/فاطمة محمد عبد الوهاب الخليفة )

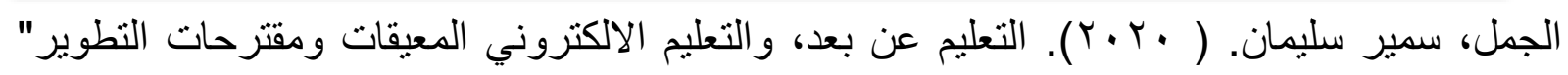

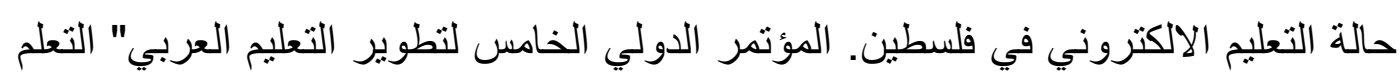

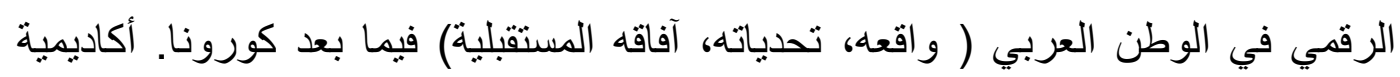

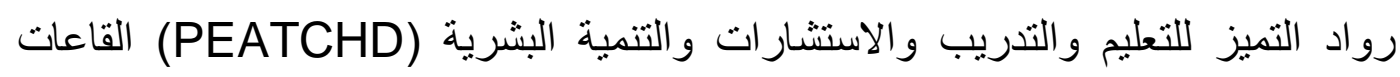

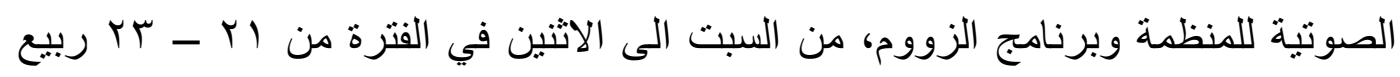

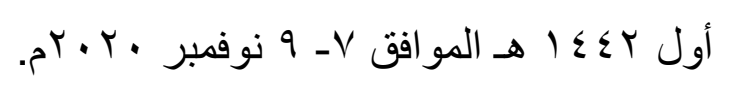

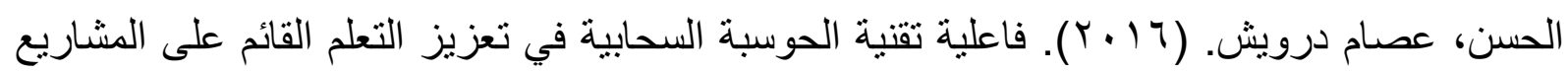

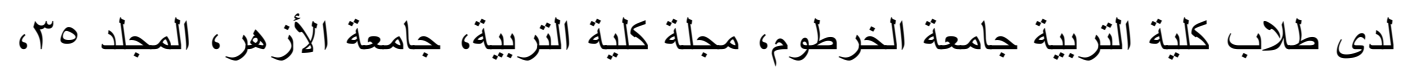

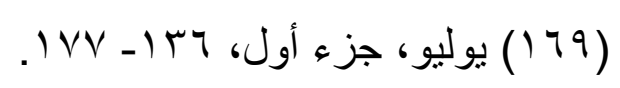

الدسوقي، محمد إبر اهيم و عبد الوهاب، فاطمة محمد، أبو سقاية، رشا يحيى السيد، المليجي، أسماء عبد

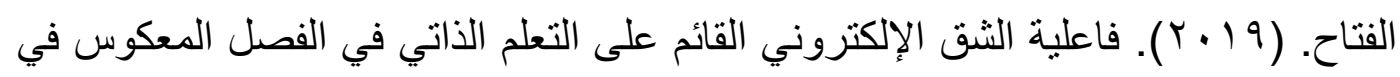

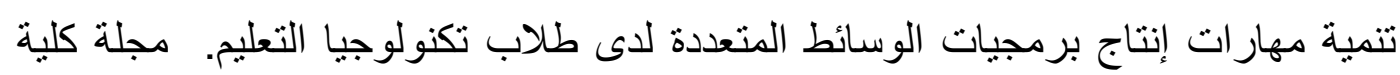

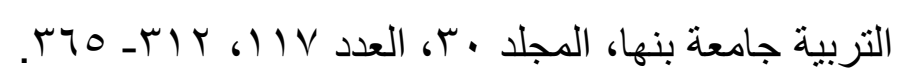

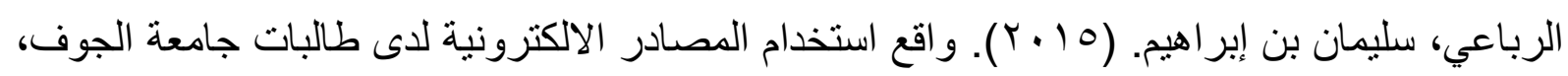

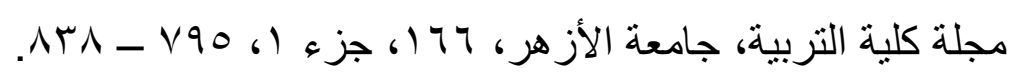

رضوان، فوقية حسن. (·r.r.r). و اقع استخدام المعلم لوسائط الاتصال و التو اصل الالكترونية وفيروس

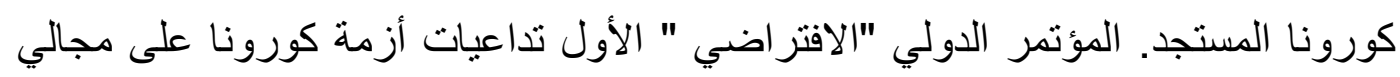

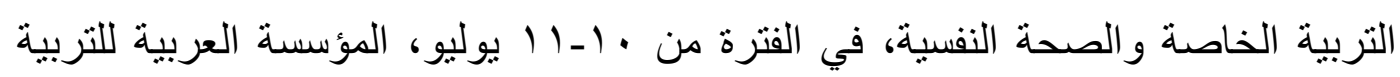
و العلوم والآداب بالتعاون مع مجمو عة قادرون للتدريب و التربية الخاصة.

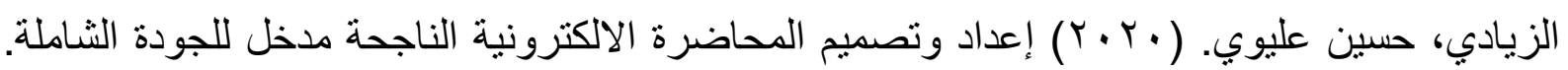
المؤتمر الدولي الخامس لتطوير التعليم العربي" التعلم الرقمي في الوطن العربي ( واقعها،

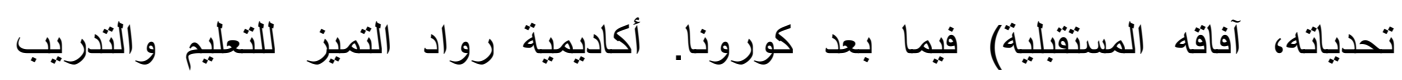

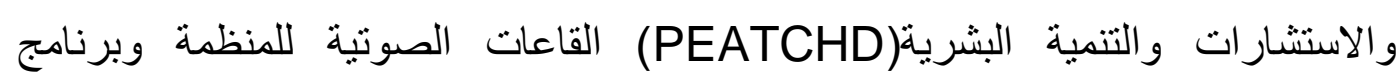

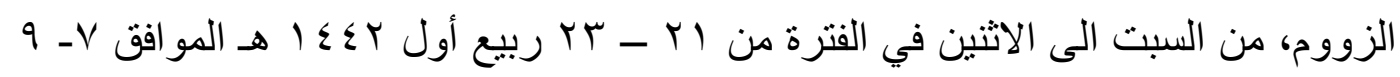

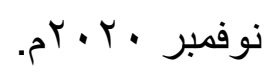


الآثار التريوية للتعليم عن بعد لاى طلاب الجامعات أثناء جائحة كورونا (أ.د/فاطمة محمد عبد الوهاب الخليفة )

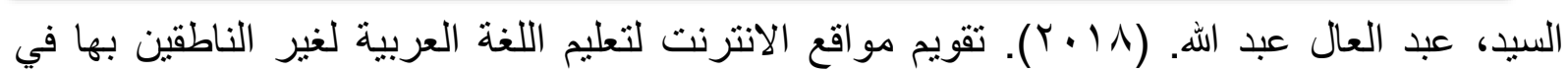

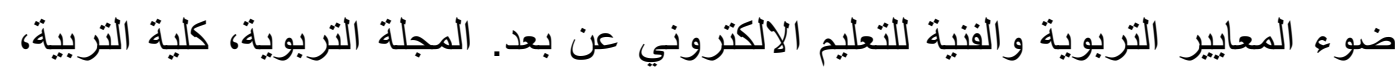

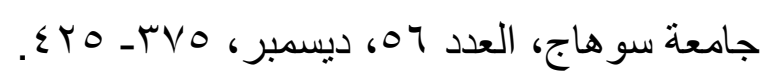

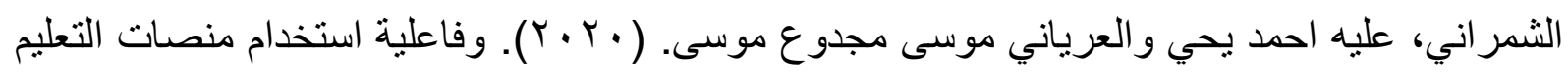

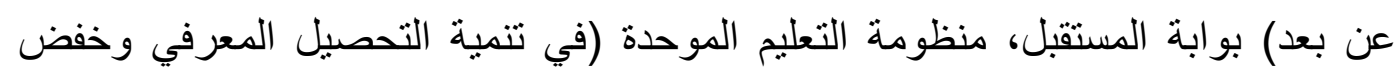

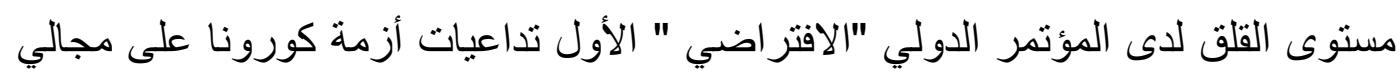

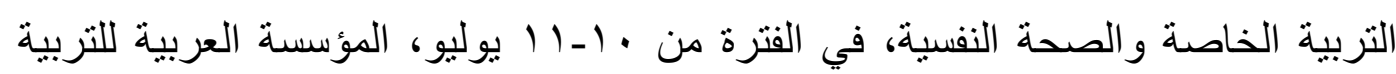
و العلوم و الآداب بالتعاون مع مجمو عة قادرون للتدريب و التربية الخاصة.

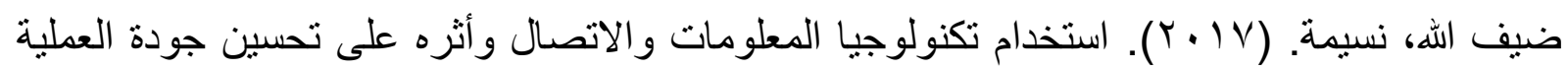

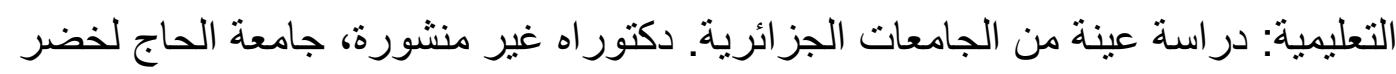

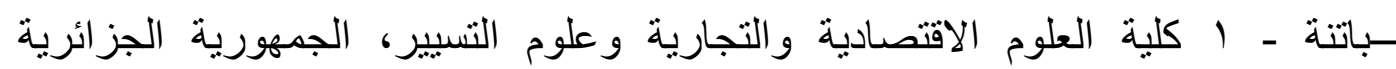
الديموقر اطية الثعبية.

عبد المنعم، منصور و عبد الحفيظ، لبنى نبيل و عبد العليم، نرمين عادل. (9 ( ب). أثر استخدام الرحلات

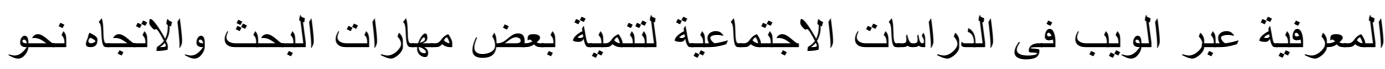

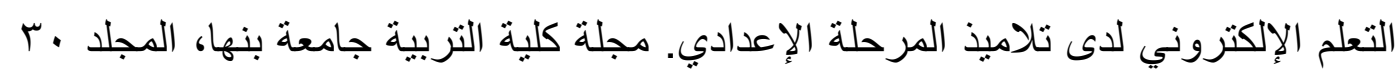

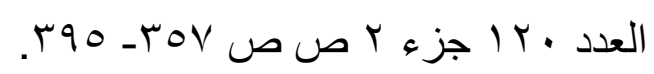

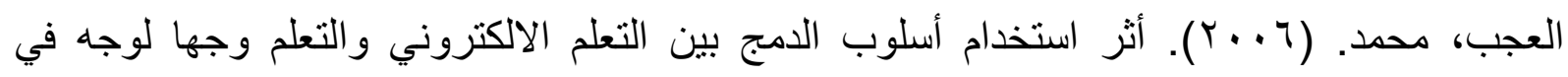

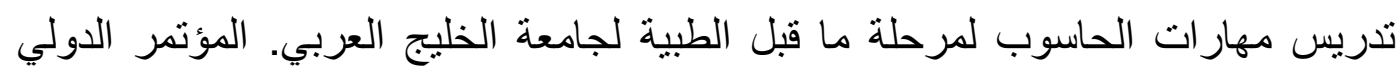

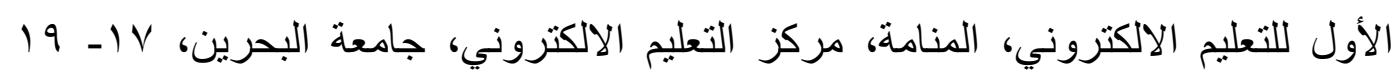
أبريل.

العطار ، سمر جابر (9 (ب). دور الرحلات المعرفية عبر الويب في تتمية مهارات الأداء اللغوي لدى

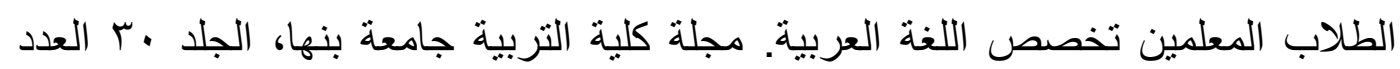

$$
\text { (19 } 119
$$

عطية، إبر اهيم أحمد وجاد الحق، نهلة عبدالمعطي و شعبان، منى عبد المنعم.(9 (ب). فاعلية برنامج إلكتروني قائم على الحوسبة السحابية في تنمية مهارات البرمجة لدى طندئ طلاب تكنولوجيا 
الآثار التريوية للتعليم عن بعد لاى طلاب الجامعات أثناء جائحة كورونا (أ.د/فاطمة محمد عبد الوهاب الخليفة )

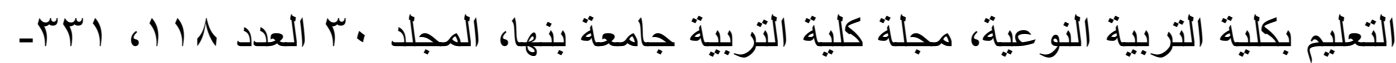

.

عليمات، صالح ناصر. (Y . . (Y). التعليم الجامعي عن بعد، المعيقات، والتطلعات المستقبلية. المؤتمر القومي السنوي التاسع، التعليم الجامعي عن بعد رؤية مستقبلية. مج ا، مركز التطوير الجامعي، جامعة عين شمس، 9 ــ - 01.

عوض، حسني محمد و أبو بكر، إياد فايز. (Y Y (Y) أثر نمط التعليم المدمج على تحصيل الدراسين في جامعة القدس المفتوحة، فلسطين. مجلة العلوم التربوية و النفسية. با، (Y)، يونيو، 90 بـIr

غيث، عمر أحمد وصالح ، فتحي عبد القادر والعجب، العجب محمد. (^ . . ץ). أثر الدمج بين التعلم عن بعد و التعلم وجها لوجه على التحصيل الدراسي ورضا الطلاب دراسة تجريبية على مقرر استر اتيجيات التدريس في كلية التربية بجامعة البحرين. بحث مستل من رسالة ماجستير، كلية الدر اسات العليا، جامعة البحرين.

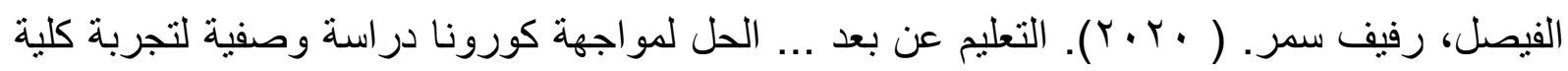
الخوارزمي الدولية". المؤتمر الدولي "الافتراضي " الأول تداعيات أزمة كورونا على مجالي التربية الخاصة و الصحة النفسية، في الفترة من · اـ ال يوليو، المؤسسة العربية للتربية والعلوم والآداب بالتعاون مع مجموعة قادرون للتدريب والتربية الخاصة.

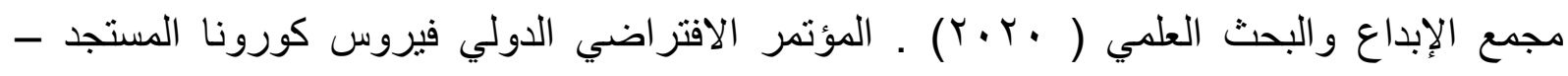

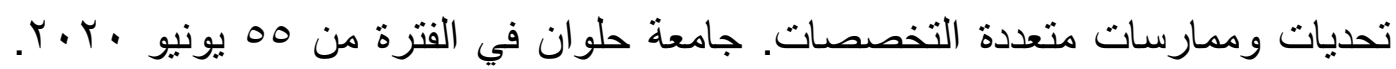

\section{http://www.helwan.edu.eg/?p=30629}

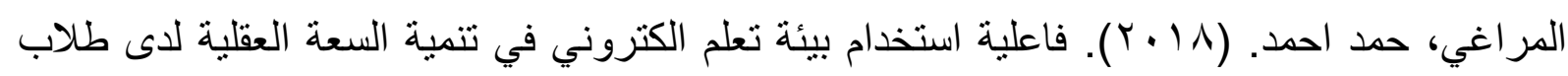
التعليم التانوي الصناعي. المركز القومي للبحوث التربوية والتعليمية، سب، ( () يناير،

$$
r \leqslant q-r .0
$$

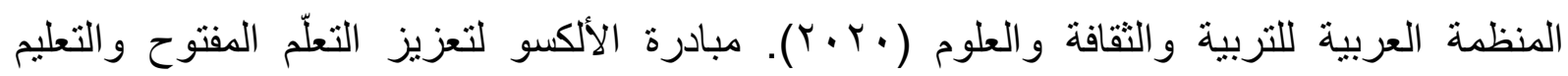
الإلكتروني بسبب أزمة كورونا. 
الآثار التريوية للتعليم عن بعد لاى طلاب الجامعات أثناء جائحة كورونا

(أ.د/فاطمة محمد عبد الوهاب الخليفة )

المؤتمر الدولي "الافتراضي " الأول تداعيات أزمة كورونا على مجالي التربية الخاصة والصحة النفسية، في الفترة من • 1 ـ1 يوليو، المؤسسة العربية للتربية والعلوم و الآداب بالتعاون مع مجمو عة قادرون للتذريب و التربية الخاصة.

النصر، مدحت أبو النصر (·r.r. (Y). الآثار الاجتماعية السلبية والإيجابية المترتبة على جائحة فيروس كورونا. المؤتمر الدولي الخامس لتطوير التعليم العربي" التعلم الرقمي في الوطن العربي ( و اقعه، تحدياته، آفاقه المستقبلية) فيما بعد كورونا. أكاديمية رواد التميز للتعليم والتدريب والاستشارات و التنمية البشرية(PEATCHD) القاعات الصوتية للمنظمة وبرنامج

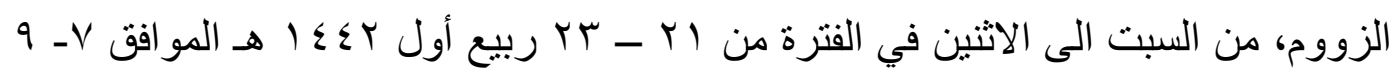

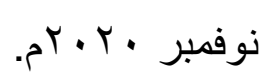

Alhussain, T., (2012). Measuring the impact of the Blackboard system on blended learning students, learning. 8, (3).

Diab, Abeer Ali Mahmud ( 2019) .Using Some Online-Collaborative Learning Tools (Google Docs \& Padlet) to-Develop Student Teachers' EFL Creative Writing Skills and Writing Self Efficacy . 